\title{
Distribution and numbers of wintering sea ducks in Swedish offshore waters
}

\author{
Utbredning och antal av övervintrande havsänder i svenska utsjövatten
}

\author{
LEIF NILSSON
}

Abstract

\begin{abstract}
The first survey of seaducks covering the offshore waters of the entire Baltic was undertaken in 1992/1993, when, however, the Swedish waters were covered with relatively few ship surveys. The second all Baltic survey 2007-2011 included extensive aerial surveys of all Swedish offshore waters. This paper presents the Swedish data from these two surveys, supplemented with data from several other but partial surveys back to the early 1970s. The most numerous wintering seaduck in the Swedish waters was the Longtailed Duck Clangula hyemalis with an estimated population of 1.41 million in $1992 / 1993$, decreasing with $69 \%$ to 0.44 million in 2007-2009. Hoburg bank south of Gotland
\end{abstract}

and the two Midsjö banks accounted for the vast majority of these ducks. In 2009-2011 only small numbers of scoters Melanitta fusca and M. nigra were found in Swedish Baltic waters. The totals for the Eider Somateria molissima and Red-breasted Merganser Mergus serrator were estimated at 20000 and 8000, respectively. Larger numbers of Eiders (50 $000)$ and scoters $(20000)$ were found on the west coast.

Leif Nilsson, Lund university, Department of Biology, Ecology Building, S-22362Lund, Sweden.Email:Leif.Nilsson@ biol.lu.se.

Received 16 March 2012, Accepted 29 March 2012, Editor : S. Svensson

\section{Introduction}

Annual counts of wintering waterbirds have been undertaken in Sweden since 1967 as a part of the International Midwinter Counts organized by what is now Wetlands International (see Nilsson 2008 for a review of the Swedish studies and references to the international work). These surveys are now a part of the Swedish Bird Monitoring Program organized by The Swedish Environmental Protection Agency (SEPA, Naturvårdsverket). During the early years the counts aimed at the largest possible coverage (Nilsson 1975) but they were early focused on covering a representative sample of sites to produce annual indices for the major wintering species but also including country-wide surveys in some years.

During the period 1965-1978 a large number of boat surveys were undertaken in Swedish waters from the patrol boats of the Swedish Coast Guard and extensive areas in the archipelagos and off the more open coasts of southern Sweden were covered (Nilsson 1972, 1980). Extensive aerial surveys were also undertaken along the open coasts of south Sweden and in the Baltic archipelagos but also on the west coast (Nilsson 1975). Some offshore aerial surveys were also performed during this period.
The early surveys in near-shore areas and in the archipelagos during the sixties and seventies gave some information about the distribution and numbers of seaducks in these waters, for which only limited data were available earlier (see however Mathiasson 1970). In those years it was not possible to cover the offshore banks of the Baltic such as the Midsjö banks and Hoburgbank, which were known to have large numbers of wintering Longtailed Ducks Clangula hyemalis. In the early years the value of the surveys was limited as it was not possible to get any information from the offshore areas in the eastern and southeastern parts of the Baltic.

After the political changes in Eastern Europe it became possible to survey the whole Baltic in the early 1990s, and in 1992 and 1993 the first coordinated census of the wintering waterbird populations of the entire Baltic was organized (Durinck et. al. 1994), for the first time producing distribution maps and population estimates for the Baltic Sea. A second survey of the entire Baltic was undertaken during 2007-2010, the SOWBAS project (Status of Wintering Waterbird Populations in the Baltic Sea; Skov et al. 2011).

In the present contribution I summarize the re- 
sults of the SOWBAS project for Swedish waters including surveys in the Swedish Economic Zone of the Baltic Sea during 2010 and 2011 with the aim to develop a monitoring program for seabirds. The recent counts are compared with the population estimates based on modeling exercises from the first all-Baltic survey (Durinck et al. 1994) and regional estimates from the offshore areas that were covered in the seventies (cf. Nilsson 1975, 1980). To make the picture more complete I also include a special survey of wintering Eiders Somateria mollissima and Scoters on the west coast in 2009.

The species covered here are the offshore species that are not properly covered by the regular midwinter counts in the inner coastal areas, i.e. Longtailed Duck, Common Scoter Melanitta nigra, Velvet Scoter Melanitta fusca, Eider and Red-breasted Merganser Mergus serrator. The latter two species do also occur in inshore areas in such numbers that annual indices can be calculated but they also have important offshore populations and are therefore included here. Other diving ducks considered as seaducks and occurring in Swedish waters are fully covered by the counts in inshore areas and will not be dealt with here see Nilsson (2008).

\section{Material and methods}

In the 2007-2011 survey the offshore areas were covered by line transects from an aircraft. The census lines were laid out so that all important water areas (including the offshore banks) in the Swedish part of the Baltic were covered out to a depth of about $30 \mathrm{~m}$. The survey lines started at the shore

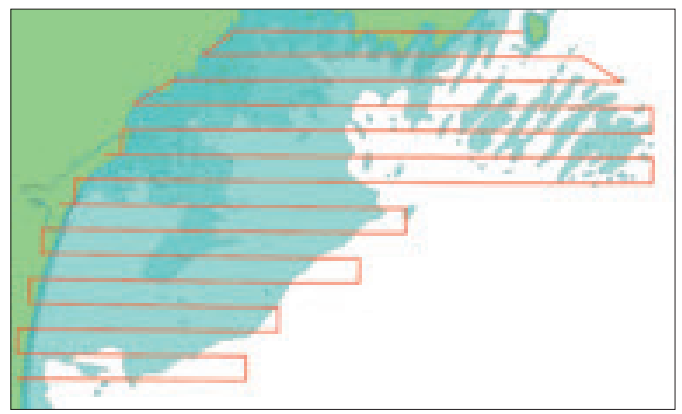

Figure 1. Example of lines used for aerial surveys in Hanöbukten in south Sweden. Here the lines are $2 \mathrm{~km}$ apart but in the main areas we used $4 \mathrm{~km}$ between the survey lines. The shades of blue refer to depths of $<6 \mathrm{~m}$ (darkest), 6-10 $\mathrm{m}$ and 10-20 m (lightest).

Exempel på inventeringslinjer i Hanöbukten. Linjerna låg här med $2 \mathrm{~km}$ mellanrum, men vi utnyttjade $4 \mathrm{~km}$ mellanrum inom merparten av de svenska farvattnen. De blå nyanserna avser havsdjupen $<6$ m (mörkast), 6-10m och 10-20 m (ljusast). or in the extensive east coast archipelagos (mainly the Stockholm archipelago) from the inner larger islands and proceeded to deep water $(30 \mathrm{~m})$. Generally there was a distance of $4 \mathrm{~km}$ between the survey lines but in some special areas (e.g. Hanöbukten) there was a distance of $2 \mathrm{~km}$ between the lines. An example of the layout of the survey lines is given in Figure 1.

The main study area for the survey was the Baltic, but in 2009 we extended the counts to include the offshore areas on the Swedish west coast to cover the wintering Eiders and Scoters there. Line transects were used in the southern part (province of Halland) whereas an area based complete survey was made in the outer archipelagos of Bohuslän.

For the surveys a Cessna 337 Skymaster, a twinengined high-winged aircraft with good visibility was used. The flying altitude was about $70 \mathrm{~m}$ and the speed $150-180 \mathrm{~km} / \mathrm{h}$, i.e. the slowest possible. Aerial surveys were only undertaken in good weather conditions. Fixed waypoints at the ends of each transect were established and navigation was undertaken with the aid of the GPS of the aircraft. Another GPS recorded the actual flight path taking positions every ten seconds. Two observers covered each side of the aircraft. All observations were recorded on tape with time and were later transferred to a data-base with the positions from the GPS recordings.

All waterbirds were counted within a belt extending $200 \mathrm{~m}$ on either side of the aircraft (called the main belt). As there was a dead angle zone of $60 \mathrm{~m}$ below the aircraft, we covered a $320 \mathrm{~m}$ wide zone. In this paper I use only the counts from this main belt. However, we also recorded observations of flocks outside the main belt. The counts from the main belt were used to estimate regional totals for the different species using expansion factors based on the coverage of the different regions $(4000 \mathrm{~m} / 320 \mathrm{~m}$ gives an expansion factor of 6.25 and $2000 \mathrm{~m} / 320 \mathrm{~m}$ an expansion factor of 12.5 for transects separated by 2 and $4 \mathrm{~km}$, respectively).

The official start of the SOWBAS survey was in 2007, but due to the weather conditions only a small part of the Swedish Baltic coast from the Falsterbo peninsula to the northern part of Öland could be covered. In 2008 the weather was also unsuitable for aerial surveys and only restricted flights could be made. In 2009, on the other hand, we managed to cover the entire Swedish coast of interest for the offshore species, i.e. from the Norwegian border on the west coast to Gävlebukten in the Baltic (Figure 2). 2009 was a mild winter with very limited ice cover in coastal wa- 

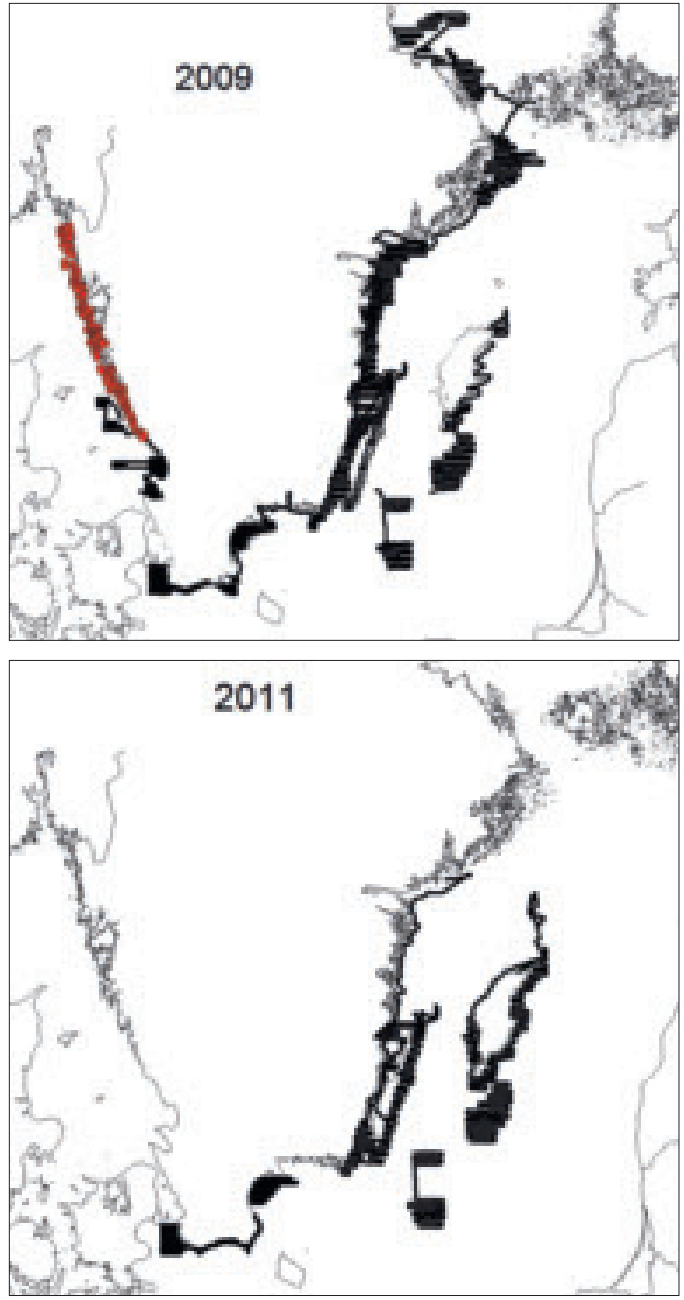

ters, restricted to the innermost bays of the archipelagos.

The 2010 winter was a contrast to 2009 , being the coldest winter since 1987. The archipelagos got covered by ice early and at the time of the survey there was compact ice from the Stockholm archipelago to Finland. The major offshore banks were surveyed during the winter but parts of the archipelagos could not be covered until the first days of April. Coverage of the counts in 2010 is seen from Figure 2.

2011 was another cold winter with very cold weather already in December 2010. There was open water along the south coast in Scania, but the archipelagos from Kalmarsund in the south were totally frozen and there was only small areas of open water in the outermost parts of the archipela-

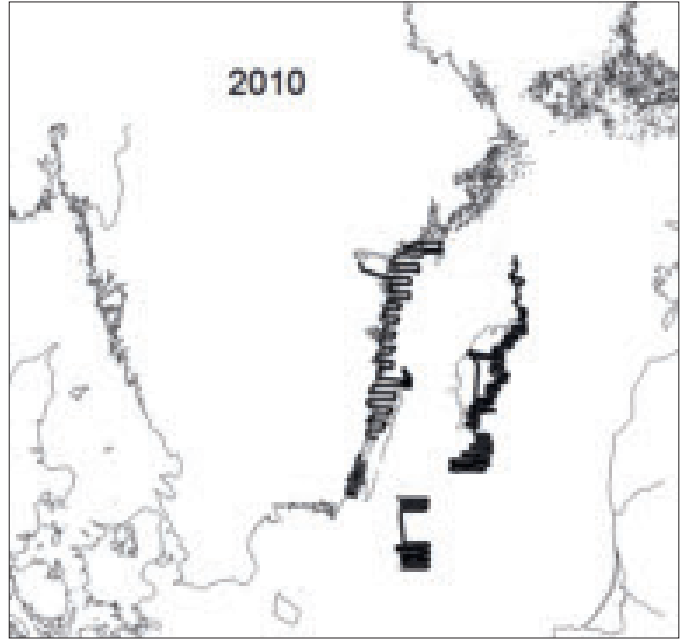

Figure 2. Coverage of the aerial surveys in offshore Swedish waters in the winters 2009, 2010 and 2011. Black lines = line transects, red dots = area-based counts. For ice cover in 2011, see Figur 3.

Täckningen med flyginventeringar i svenska utsjöområden vintern 2009. Svarta linjer = linjetaxeringar, röda punkter $=$ områdesbaserade inventeringar. För istäcke 2011, se Figur 3.

gos north of Kalmarsund (Figure 2). The ice extended east over the Baltic Sea and the important offshore areas in the Baltic republics were all icecovered (Figure 3 ).

The southern parts of the Baltic could be covered during the winter proper, whereas the archipelagos further north could not be covered until the first days of April in some cases. This is of no problem for the Long-tailed Ducks that leave the Baltic in May but the late surveys could not be used for the Eider and the Scoters. These species are however present in small numbers in these areas during the winter as shown by the countrywide surveys of the archipelagos. The offshore surveys in 2009 were for some species supplemented by observations from the annual midwinter counts for some inshore areas (mainly on west 
Gotland), which were not extensively covered by the aerial surveys.

The efficiency of aerial surveys of different species was much studied during the seventies by air/ ground comparisons for different species in different habitats (Nilsson 1975, cf. also Joensen 1974). In these studies marked differences in the survey efficiency was found between species but also between different observers as was also found for aerial surveys in the breeding areas (Haapanen \& Nilsson 1979). The surveys during the seventies were area based, whereas the aerial surveys of the Swedish waters during the SOWBAS study were performed as line transects, so there might also be differences between the two kinds of aerial surveys.

One possible source of bias applying to the line transects undertaken during 2007-2011 is the possibility to see if the flocks observed are within the main belt or not. The inclusion of flocks outside this belt in the calculations would lead to an overestimate of the number of seaducks in an area. On the other hand some birds will be missed during the counts as they may be under water during the passage of the aircraft. The earlier studies (Nilsson 1975) did however establish that a relatively high proportion of the birds present in an area were actually seen from the aircraft during the passage.

When comparing the estimates for Swedish waters presented here with the population estimates for NW Europe presented by Delany \& Scott (2006) and with the two All Baltic surveys (Durinck et al. 1994, Skov et al. 2011) it is important to bear in mind the differences in methods used as well as the different uncertainties and biases attached to the two methods. These factors will also have great importance when evaluating the population changes indicated in the report from the SOWBAS study (Skov et al. 2011).

For the Swedish waters the estimates presented here and included in the SOWBAS report (Skov et al. 2011) are all based on aerial line transects, whereas no aerial surveys could be undertaken during the 1992/1993 study. The estimates for Swedish waters in 1992/1993 were based on relatively few ship transects in some offshore areas, whereas many areas were very poorly covered with transects lines (see Durinck et al. 1994, map 4 , for coverage), the estimates to a large extent being based on modeling exercises. The regional estimates from 1992/1993 presented in the tables are therefore considered to be imprecise. The overall estimates for the Baltic in the SOWBAS study were also based on modeling (Skov et al. 2011), whereas the estimates presented here are based on the totals from the line transects adjusted for coverage with the expansion factors presented above.

The overall Baltic survey in 1992/1993 included aerial surveys in some of the other countries but did rely heavily on boat transects for the offshore areas. As there are very marked differences in methods and coverage for the Swedish waters (and some other areas) between the two all Baltic surveys, the estimates from this survey must be regarded with large caution.

For the Long-tailed Duck, estimates are also presented for the period 1966-1974. For the areas in Scania and Blekinge these are based on line transects from patrol boats of the Swedish Coastguard. Details for these surveys including survey lines were published by Nilsson (1980). These counts were considered to cover $500 \mathrm{~m}$ on each side of the ship, based on which mean densities were calculated for different sectors. The densities were assumed to apply for areas out to $20 \mathrm{~m}$ depth. Estimates for the east and north coasts of Öland and for the areas east and north of Gotland were based on an aerial survey in 1974 and density estimates from line transects by boats. In the calculations the aerial survey was considered to cover $250 \mathrm{~m}$ on each side of the aircraft. The densities obtained from the boat surveys and aerial surveys were used to get a rough estimate for the total wintering populations based on the experiences of the distribution of Long-tailed Ducks from later more extensive surveys. Early estimates for the archipelagos from northern Kalmar to Stockholm were based on total surveys of the areas and have been published by Nilsson (1975).

\section{Results}

\section{Long-tailed Duck Clangula hyemalis}

The Long-tailed Duck is mainly restricted to the Baltic during the winter and only very small numbers are found on the west coast. The species is distributed from Falsterbo in the southwest to Finngrunden in Gävlebukten to the north (Figure 3). The absolute majority of the Long-tailed Ducks in Swedish waters in 2009 were found on the three offshore banks: Hoburg bank, N. Midsjö bank and S. Midsjö bank. In all 300000 out of an estimated total for the Swedish waters of 436000 in this winter were found here (Figure 3, 4, Table 1,2).

Besides the three large offshore banks, important numbers of Long-tailed Ducks were also found on the east coast of Gotland and around Öland (Figure 3, Table 1). The areas north of Gotland were 

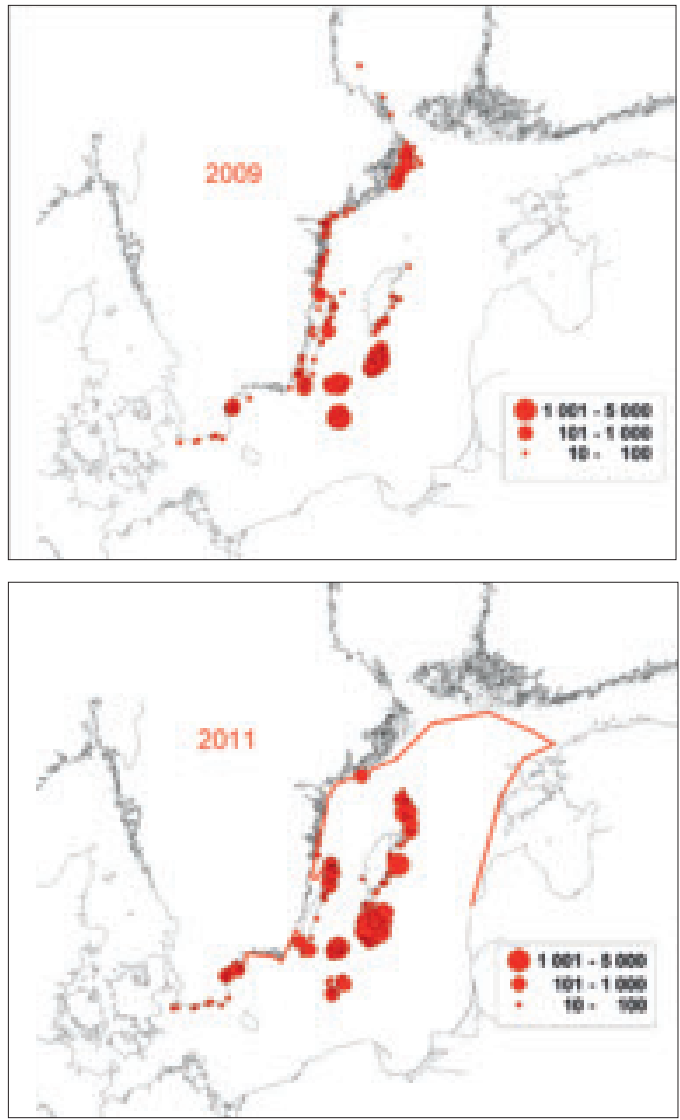

Figure 3. The distribution of Long-tailed Duck Clangula hyemalis in Swedish waters in the mild winter 2009 and the cold ice-winter 2011. The red line $=$ border of ice.

Utbredningen för alfågel Clangula hyemalis $i$ svenska farvatten den milda vintern 2009 och den kalla isvintern 2011. Röd linje $=$ isgränsen .

not surveyed in 2009 but important numbers were found here in other years. On the mainland coast only small numbers were counted on the south coast of Scania, and larger flocks from Hanöbukten and Kalmarsund north to Stockholm in the outer zone of the archipelagos (Figure 3).

In the two winters of 2010 and 2011, with hard ice conditions, the distribution of the Long-tailed Duck in Sweden was markedly different. Large numbers were concentrated to the offshore banks, with an estimated total there of 630000 in 2010 and 365000 in 2011. In 2010426000 of these Longtailed Ducks were found on Hoburgbank (Table 1, Figure 4). The high counts on the offshore banks in 2010 and 2011 can most probably be related to the ice situation, especially on the eastern Baltic coast, where the important winter areas for the species

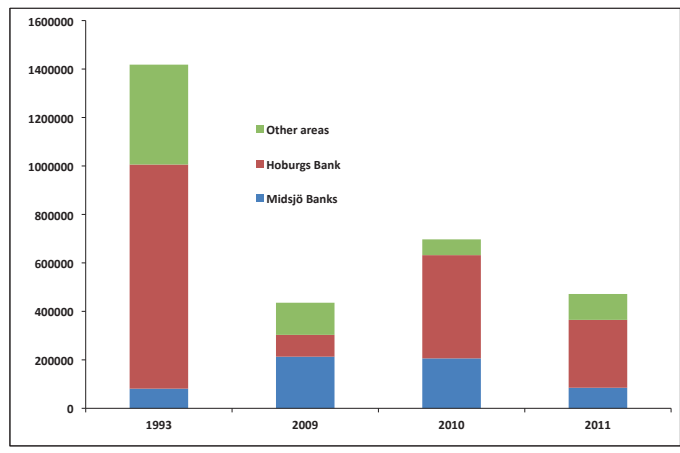

Figure 4. The estimated population of Long-tailed Duck Clangula hyemalis on the offshore banks and in other Swedish areas during the surveys in 1992/93, 2009, 2010 and 2011.

Det beräknade beståndet av alfågel Clangula hyemalis på de viktiga utsjöbankarna och andra svenska områden vid inventeringarna 1992/93, 2009, 2010 och 2011.

such as Irbe strait and the Riga bay were totally ice-covered in 2010 and 2011.

The occurrence of Long-tailed Ducks on the three major offshore banks will be further discussed in another context, so I will not go into any details here. On Hoburgbank marked differences were found between the three years, related to the ice situation in the Baltic. On the Midsjö banks on the other hand the totals found in 2009 and 2010 were largely similar, but numbers were appreciably lower in 2011. The northern Midsjö bank however had similar totals for all three years (Table 2).

Compared to the first total survey of the Baltic sea in 1992/1993 there were marked differences in the total number of Long tailed Ducks estimated for the Swedish part of the Baltic in the two censuses, 1.41 million in the former compared to 0.44 million in 2009. The two estimates are however based on different methods with different kinds of bias, as discussed above.

The changes between the two major surveys are not the same for all areas. For the main areas around Gotland, Hoburgbank and the Midsjö banks, very marked differences were found between 1992/1993 and 2009. Estimates for Hoburgbank were 90000 in 2009 compared to 925000 in 1992/1993. For the east coast of Gotland the estimates for the two surveys were 11000 compared to 270000 . Numbers on the Midsjö banks were markedly higher in 2009 than in 1992/1993 but this does not compensate for the decrease on Hoburgbank. Counts in 2009 and 2010 were similar but numbers were markedly lower on the southern Midsjö bank in 2011 than in the two previous years (Table 2) but there was no 
Table 1. Estimated totals of Long-tailed Ducks Clangula hyemalis in different areas along the Baltic coast of Sweden. Distribution maps 2009 and 2011 in Figure 3; lack of agreement between table and map depends on superimposition of dots and different division into sections. A dash indicates absence of count.

Beräknat antal alfåglar Clangula hyemalis inom olika delområden på den svenska kusten vid olika tillfällen. Utbredningskartor 2009 och 2011 i Figur 3; brist på överensstämmelse mellan tabell och karta beror på att punkter ligger på varandra och att områdesindelningen är olika. Ett streck anger avsaknad av räkning.

\begin{tabular}{lrrrrrr}
\hline Area & $1967-74$ & $1992-93$ & 2007 & 2009 & 2010 & 2011 \\
\hline Falsterbo & 1400 & 500 & - & 1600 & 2800 & 1200 \\
Skåne south coast & 9000 & 800 & - & 1700 & - & 2000 \\
Skåne southeast & 7000 & 200 & - & 100 & - & 300 \\
Hanöbukten & 25000 & 17000 & 23000 & 17000 & - & 7100 \\
Blekinge archipelago & 1600 & 1100 & 300 & 100 & - & 100 \\
Kalmarsund & - & 12000 & 23000 & 11000 & 11500 & 2500 \\
Öland east coast & 40000 & 10000 & 19000 & 26000 & - & 39000 \\
Öland North banks & 60000 & 30000 & 11000 & 5000 & 7200 & 22400 \\
Midsjö banks & - & 81000 & - & 213000 & 206000 & 85000 \\
Hoburgs bank & - & 925000 & - & 90000 & 426000 & 280000 \\
Gotland east coast & 400000 & 270000 & - & 11000 & 15100 & 15700 \\
Gotland north & 20000 & 10000 & - & & 13500 & 14500 \\
Gotland west & - & 23000 & - & 2000 & - & 2000 \\
Kalmar archipelago & 10000 & 12000 & - & 14000 & 2700 & ICE \\
Östergötland archipelago & 1000 & 3500 & - & 8800 & 3200 & ICE \\
Södermanland archipelago & 4000 & 4000 & - & 4100 & 12000 & ICE \\
Stockholm archipelago & 24000 & 18000 & - & 26100 & - & ICE \\
Uppland coast & - & - & - & 3700 & - & ICE \\
Gävlebukten & - & - & - & 600 & - & ICE \\
\hline Total & & 1418100 & & 435800 & & 471800 \\
\hline
\end{tabular}

similar decrease on the northern bank.

The offshore areas around Gotland could not be covered properly during the 1970 s even if some boat transects were made along the east coast. In the winter 1974 an aerial survey was made along the entire east coast of Gotland. 26000 Long-tailed Ducks were actually counted. Taking the coverage and the experiences from later aerial surveys here into consideration it is probable that the total wintering number of Long-tailed Ducks here was in the order of 200 000-400 000. The estimates for these waters in 2009-2011 were $11000-15$ 700. It is clear that there has been a marked decrease in the waters east and north of Gotland.
From the mainland coast and the archipelagos fairly extensive data on the Long-tailed Ducks are available from the period 1971-1974 (1978). There are also some longer count series from areas where the Long-tailed Ducks can be counted more or less accurately from the shore. Regular counts of wintering ducks have been made on the coasts of south Scania between Ystad and Falsterbo Canal every winter since 1964 . The depth profile makes it possible to cover an important part of the areas used by the Long-tailed Ducks in a standardized manner. During the first years more than 1000 Long-tailed Ducks were regularly counted here in January (Figure 5) but numbers have decreased markedly over

Table 2. Total estimated number of Long-tailed Ducks Clangula hyemalis on the Midsjö banks at all aerial surveys in the area. A dash indicates absence of count.

Beräknat antal alfåglar Clangula hyemalis på Midsjöbankarna vid genomförda flyginventeringar. Ett streck anger avsaknad av räkning.

\begin{tabular}{lrrrrrr}
\hline & $2005-04-01$ & $2009-03-03$ & $2010-03-16$ & $2011-03-07$ & $2011-03-29$ & $2011-04-20$ \\
\hline Norra & - & 76000 & 74000 & 63000 & 37000 & 67000 \\
Södra & 160000 & 137000 & 132000 & 22000 & 7500 & 16500 \\
\hline Total & & 213000 & 206000 & 85000 & 44500 & 83500 \\
\hline
\end{tabular}


the years. The same was noted for the archipelago of Blekinge (Figure 5). On the other hand there were no major changes in the number of wintering Long-tailed Ducks in Hanöbukten (Table 1), although the estimated total of Long-tailed Ducks here varied between 23000 and 7100 at the different surveys in 2007-2011.

Kalmarsund was not well covered in the 1970s so there are no total estimates available. The estimates for 1929/1993, 2009 and 2010 were similar whereas many more Long-tailed Ducks were estimated here for 2007. Only few were counted here in 2011 as most of the area was ice-covered.

The east and north coast of Öland is an important area for the Long-tailed Duck. The 1992/1993 survey estimated the numbers here to about 40000 , the estimates for 2007 and 2009 being around 30000 (Table 1). In the ice winter 2011 the estimate for these areas was about 60000 but the entire Kalmarsund and the archipelagos were ice-covered and the Long-tailed Ducks had probably concentrated to the waters around Öland. From the surveys in the period 1971-1974 the estimated total for east and north Öland waters is in the order of 100000 individuals. Regular shore-bound counts in January show a marked variation in the numbers of Long-tailed Ducks counted on the coasts of northern Öland between different years without any trend (Figure 5), but the counts are much influenced by the weather conditions.

Estimates from 1971-1974 are available from the archipelagos from Kalmar to Stockholm (Table 1) showing no differences in the estimated numbers of wintering Long-tailed Ducks here comparing with the recent survey in 2009 (these areas being ice-covered in 2010 and 2011). The coast of Väddö on the Uppland coast north of Stockholm archipelago showed marked variation between different years (Figure 5).

The local distribution of Long-tailed Ducks in some areas will be discussed in some detail here as the surveys in 2007-2011 were the first ones to obtain a comprehensive coverage of the entire offshore distribution in Swedish waters. The south

Figure 5. Annual totals of Long-tailed Ducks Clangula hyemalis in four reference areas of the International Midwinter Counts during 1971-2011.

Antalet alfåglar Clangula hyemalis inom fyra referensområden vid de internationella midvinterinventeringarna 1971-2011.
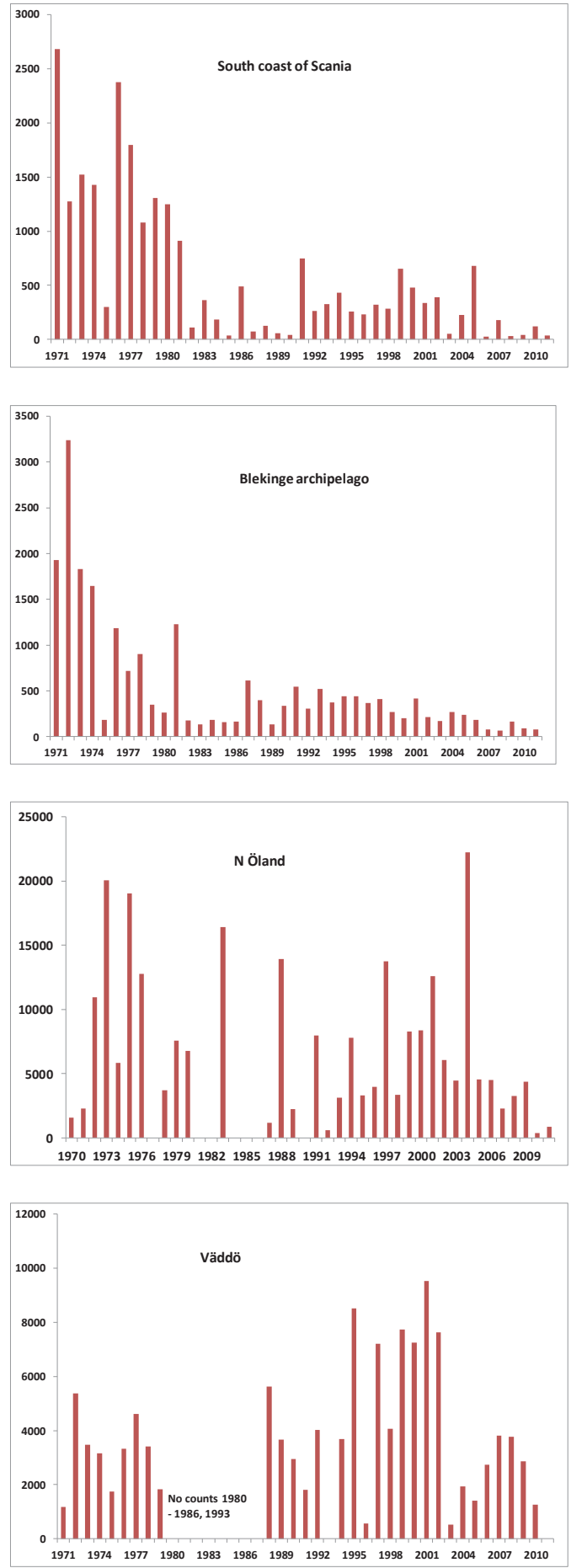

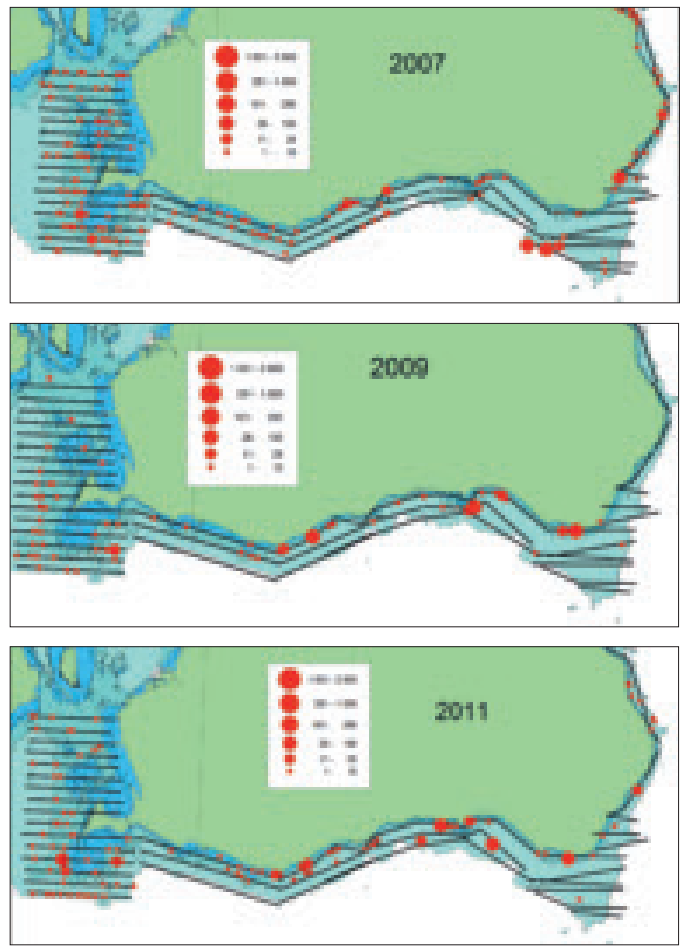

Figure 6. Number of Long-tailed Ducks Clangula hyemalis counted along the line transects off the south coast of Scania, southernmost Sweden during the winters 2007, 2009 and 2011. Black lines $=$ transect lines.

Antalet inräknade alfåglar Clangula hyemalis längs inventeringslinjer utanför den skånska sydkusten, södra Sverige, under vintrarna 2007, 2009 och 2011. Svarta linjer = inventeringslinjer.

coast of Scania has been surveyed completely from the air on three occasions during 2007-2011 (Figure 6). In the southern part of Öresund and around the Falsterbo peninsula, where detailed studies have been made (Nilsson \& Green 2011) small groups of Long-tailed Ducks were found spread in the offshore areas. The Long-tailed Ducks were found spread off the entire south coast mostly in rather shallow waters relatively close to the shore even if flocks were found out to a depth of about $20 \mathrm{~m}$. The distribution was similar during extensive boat surveys and counts from the shore during 1964-1970 (Nilsson 1972), but numbers in the area were much lower in 2007-2009 both in the offshore and inshore waters (Figure 5).

Hanöbukten in Scania is the southernmost offshore concentration area for the species in Sweden. Three surveys in 2007-2011 (Figure 7) show quite different distribution patterns. In 2007 they were highly spread out over the entire area, whereas they
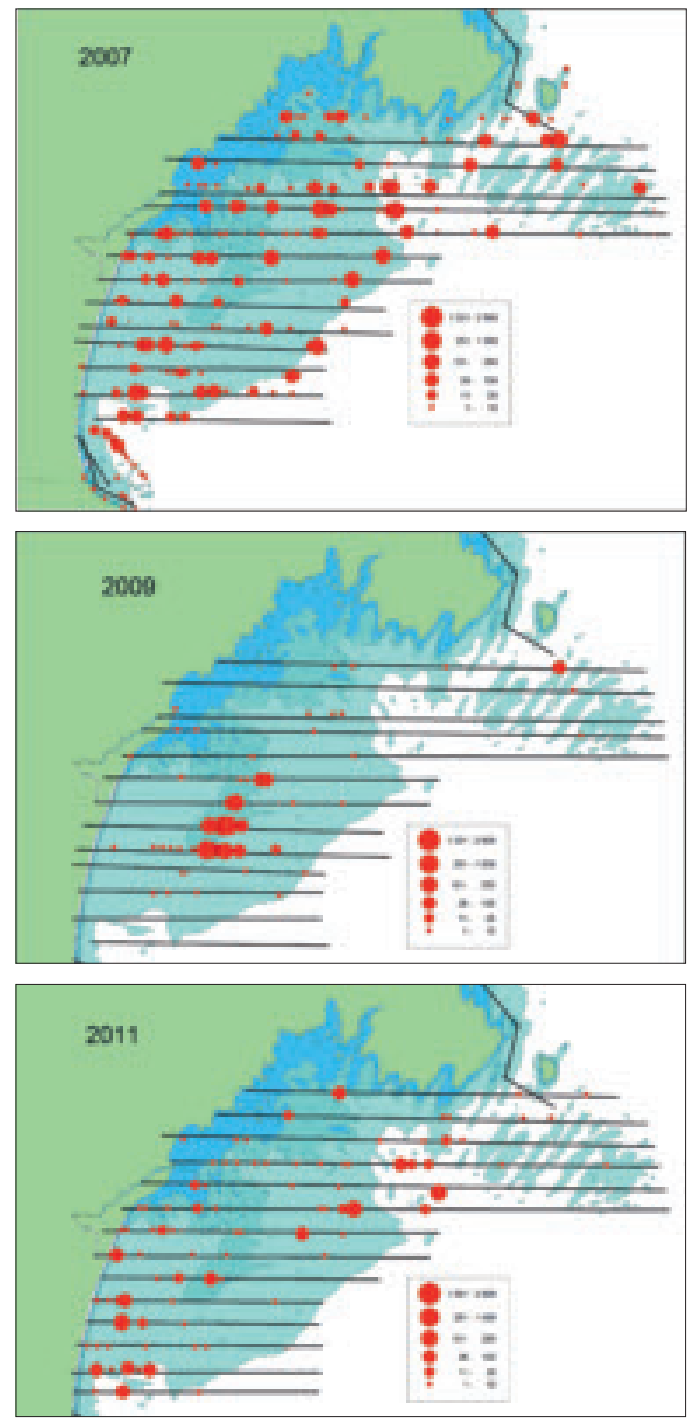

Figure 7. Number of Long-tailed Ducks Clangula hyemalis counted along the line transects in Hanöbukten, southernmost Sweden during the winters 2007, 2009 and 2011. Black lines $=$ transect lines.

Antalet inräknade alfåglar Clangula hyemalis längs inventeringslinjer $i$ Hanöbukten, södra Sverige, under vintrarna 2007, 2009 och 2011. Svarta linjer = inventeringslinjer.

were much more concentrated in 2009. The totals estimated for the two surveys were not so different, 23000 compared to 17000 , whereas much lower counts were obtained in 2011 (Table 1). The 2009 concentration was at a shallow area called Kiviksbredan, which had the highest densities of Longtailed Ducks during studies in the 1960s (Nilsson 

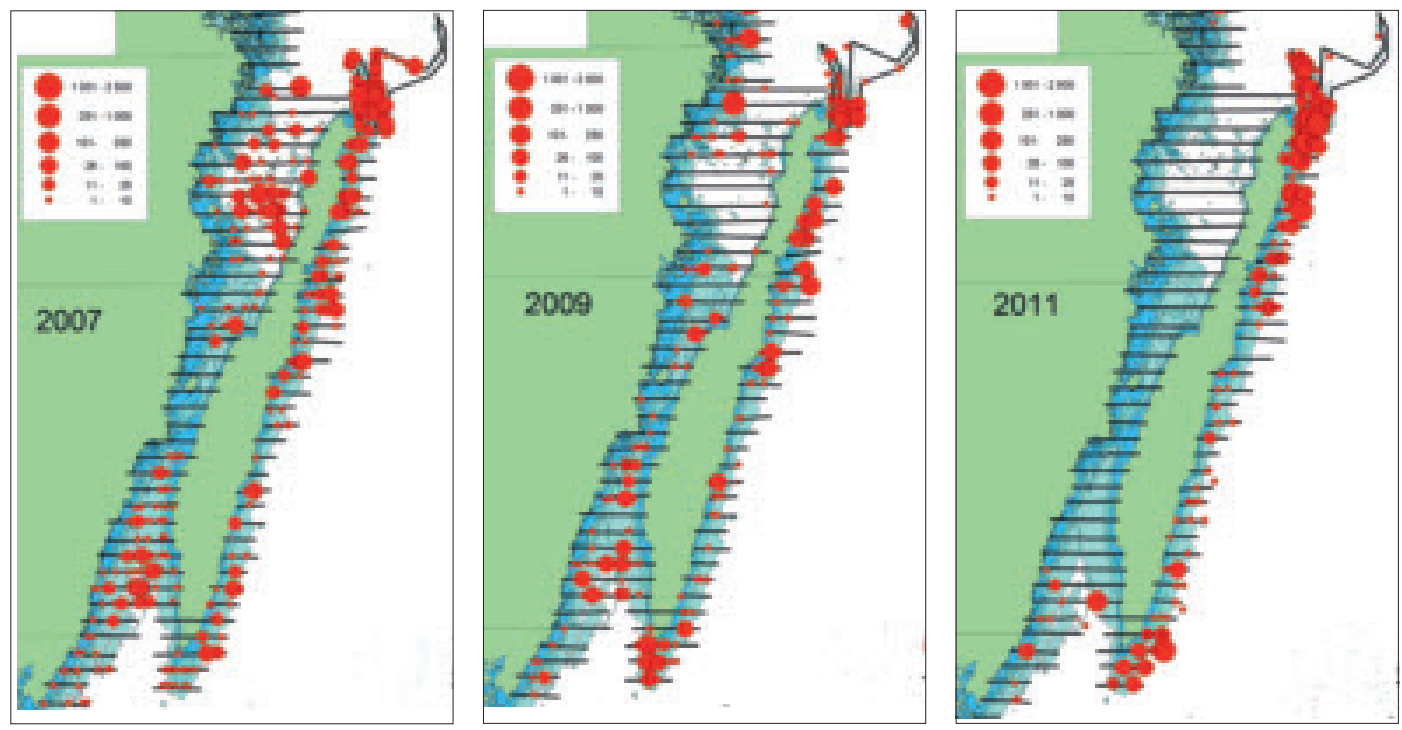

Figure 8. Number of Long-tailed Ducks Clangula hyemalis counted along the line transects in Kalmarsund and off Öland, southernmost Sweden during the winters 2007, 2009 and 2011. Black lines = transect lines.

Antalet inräknade alfåglar Clangula hyemalis längs inventeringslinjer i Kalmarsund och utanför Öland, södra Sverige, under vintrarna 2007, 2009 och 2011. Svarta linjer = inventeringslinjer.

1972) but in most other surveys the species was more spread out than in the earlier years.

Kalmarsund and Öland were totally covered in three winters (Figure 8). 2007 and 2009 were mild winters with little ice and accordingly the Longtailed Ducks were well spread both in the Kalmarsund and on the east and north coast of Öland. 2011 was a hard ice-winter and the only open water in the Kalmarsund was found in the far southern end of the area. In this winter the Long-tailed Ducks were found east and northeast of Öland, with an estimated total of 60000 individuals in this area (Table 1).

In all years concentrations of Long-tailed Ducks were found on the banks north and northeast of Öland. Large numbers were often counted from the shore in this area (Figure 5). In two of the three surveys there was also a concentration of Long-tailed Ducks around southern Öland. In the Kalmarsund there are a number of shallow banks in the southern and northern parts of the area and most flocks of Long-tailed Ducks were accordingly found here. The distribution of Long-tailed Ducks in the waters around Öland was similar in the seventies with a marked concentration to the northern banks and the northeastern coast of the island.

Long-tailed Ducks were wide-spread in the outer zones of the archipelagos all the way from the
Kalmarsund area to the northern part of the Stockholm archipelago (Figure 9). In the 2009 survey there were no larger regional differences with the exception of few Long-tailed Ducks in the southern part of the Stockholm archipelago. The inner parts of the archipelago were not covered in the 2009 survey, but counts at the countrywide aerial survey in 2004 did not show any larger numbers of Longtailed Ducks here. The distribution of Long-tailed ducks in the archipelagos was similar in the surveys during the 1970 s.

The best coverage of the offshore waters around Gotland was obtained in the ice winter 2011 (Figure 10). The species was well spread mostly in smaller groups and some flocks on the east coast and on the banks between mainland Gotland and Gotska Sandön with a flock on the isolated offshore bank Kopparstenarna. A concentration was found at Östergarn and some parts at Gotska Sandön. The counts of the east coast of Gotland in 2009 and 2010 show a similar distribution of the species but all parts were not covered. In the 1970 s very large numbers of Long-tailed Ducks were found in the waters around Fårön and the northeast of Gotland, but during the recent surveys only relatively small numbers were found here. The situation for the Long-tailed Ducks on Hoburg bank and the Midsjö banks will be addressed in another paper analyzing 

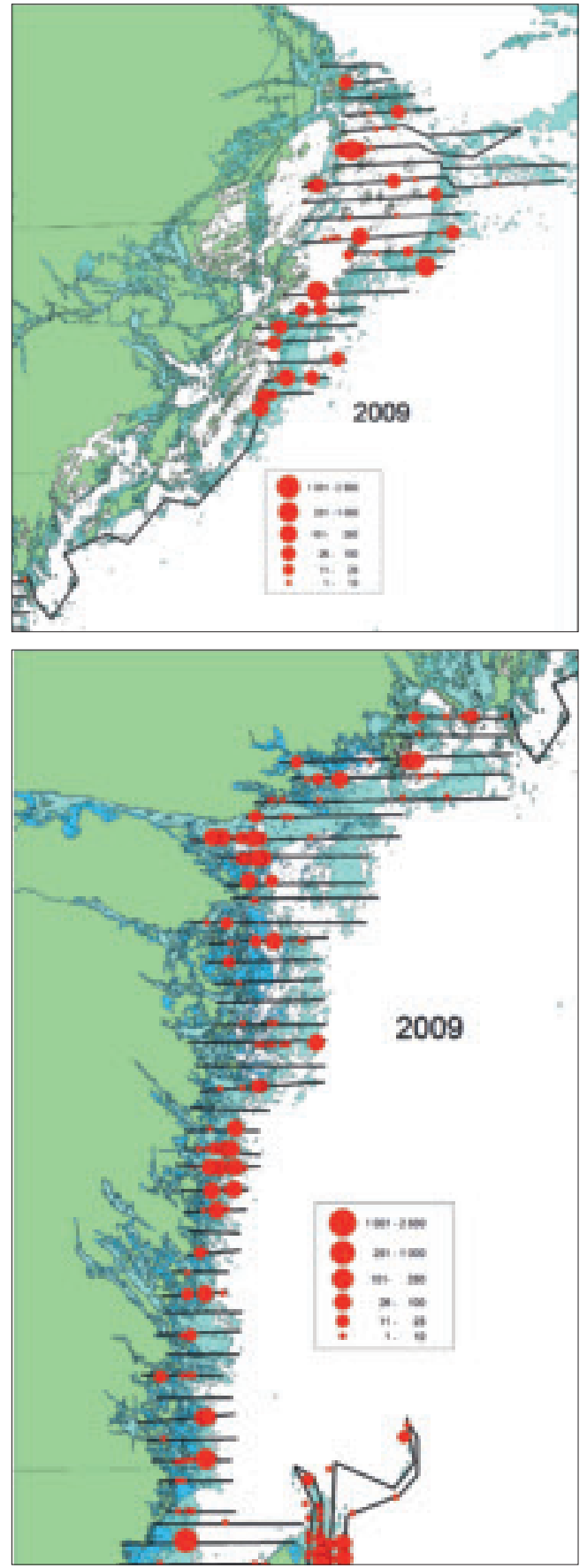

Figure 9. Number of Long-tailed Ducks Clangula hyemalis counted along the line transects in east coast archipelagos of Sweden during the winter 2009. Black lines = transect lines. Antalet inräknade alfåglar Clangula hyemalis längs inventeringslinjer i de svenska ostkustskärgårdarna under vintern 2009. Svarta linjer $=$ inventeringslinjer

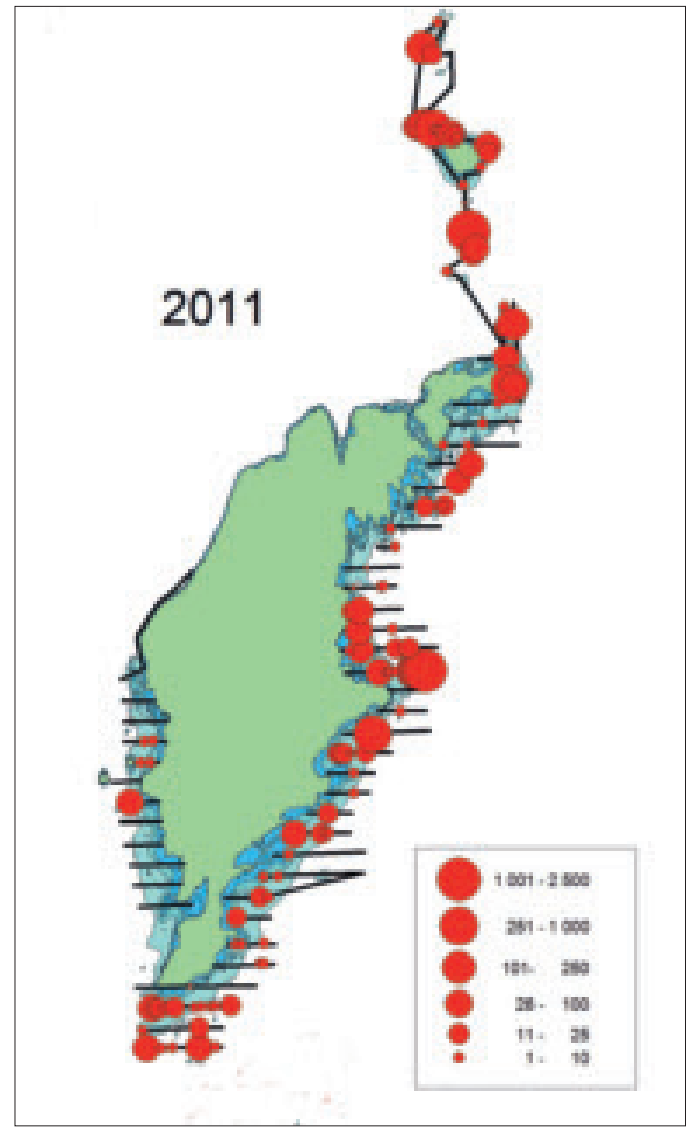

Figure 10. Number of Long-tailed Ducks Clangula hyemalis counted along the line transects at the coasts of Gotland during the winter 2011. Black lines $=$ transect lines.

Antalet inräknade alfåglar Clangula hyemalis längs inventeringslinjer vid kusterna av Gotland under vintern 2011. Svarta linjer $=$ inventeringslinjer

the distribution of the species in relation to different habitat features (Larsson, Nilsson \& Skov in prep.) but maps of the distribution on these banks from the 2009 survey are included here to make the overall picture complete (Figure 11).

\section{Velvet Scoter Melanitta fusca}

The Velvet Scoter is normally seen only in relatively small numbers in the Swedish part of the Baltic (Figure 12, Table 3). In 2007, when unusually high numbers of Common Scoters were found in parts of the Swedish Baltic, relatively high numbers of Velvet Scoters were also counted in Hanöbukten and along the east coast of Öland. Offshore counts in the waters around Falsterbo and in Hanöbukten have shown a regular occurrence of the species in 

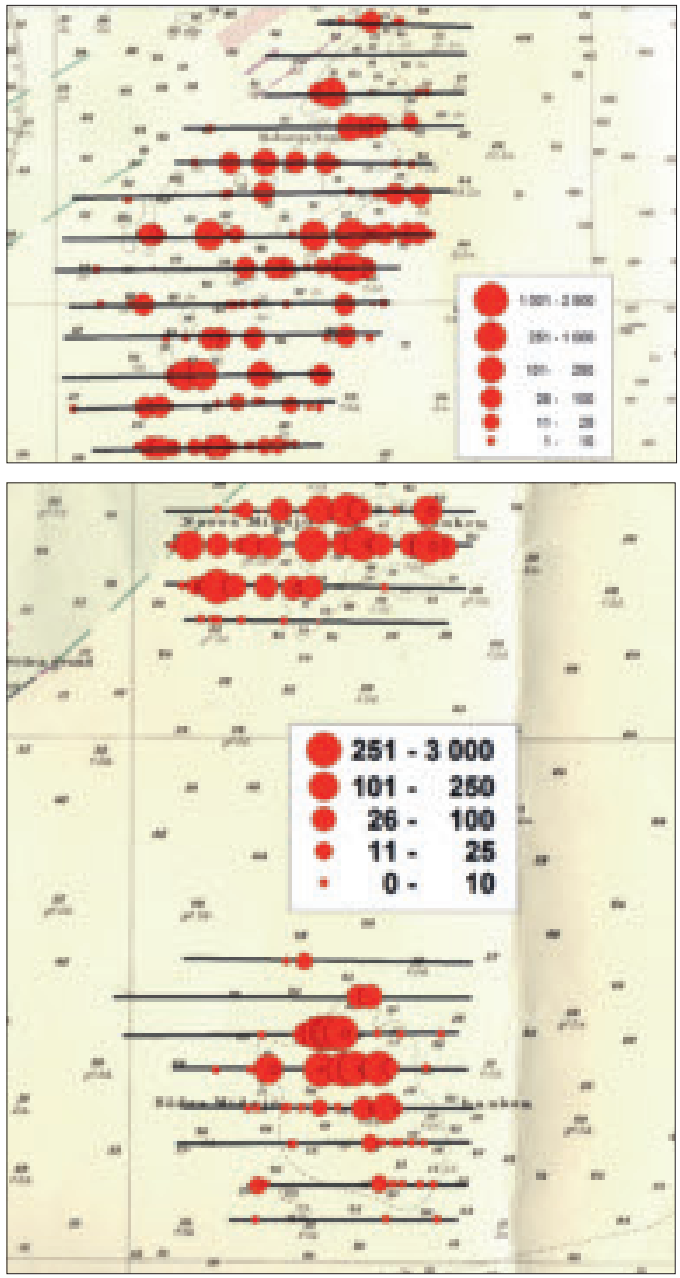

Figure 11. Number of Long-tailed Ducks Clangula hyemalis counted along the line transects on Hoburg Bank southeast of Gotland (upper map) and on the Midsjö banks southeast of Öland (lower map) during the winter 2009. Black lines = transect lines.

Antalet inräknade alfåglar Clangula hyemalis längs inventeringslinjer på Hoburgs Bank sydost om Gotland (övre kartan) och Midsjöbankarna sydost om Öland (nedre kartan) vintern 2009. Svarta linjer = inventeringslinjer.

small numbers in the winter, small numbers also occurring around Öland and Gotland (cf. Nilsson 1972, 1975, 2008, Nilsson \& Green 2011).

In the southeastern part of Kattegatt, in Laholmsbukten and Skälderviken, Velvet Scoters and Common Scoters are regularly wintering in flocks (Figure 11, Table 4). The areas are regularly covered during the standard midwinter counts, but the flocks stay too far out from the shore to be ade-

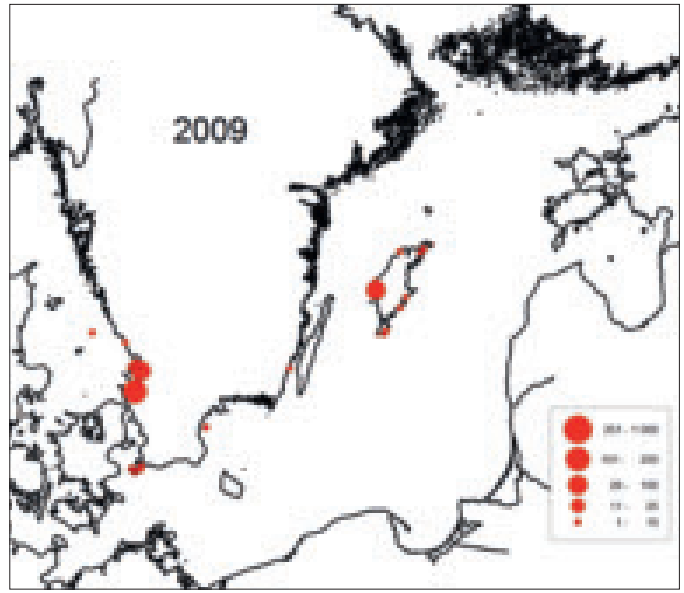

Figure 12. The distribution of Velvet Scoter Melanitta fusca in Swedish waters in the mild winter 2009.

Utbredningen för svärta Melanitta fusca $i$ svenska farvatten den milda vintern 2009.

quately covered every winter. Scoter flocks have however been recorded here since the start of the counts in the 1960s (Nilsson 1975). In 2009, this area was surveyed from the air and the total number of wintering Velvet Scoters was estimated to be around 2500, compared to about 17500 Common Scoters (Table 4, unidentified Scoters included in proportion to identified ones).

\section{Common Scoter Melanitta nigra}

The Common Scoter is a regular wintering bird in the southern part of the Swedish Baltic areas and in the southeast parts of the Kattegat (Figure 13). Normally it has been counted in relatively small numbers around the coasts of Scania, Kalmarsund and Öland, but in 2007 no less that 40000 Common Scoters were estimated to be present in the offshore waters here compared to 1500-2000 in the other years (Table 5). Numbers were much lower in 2009 but a flock of no less than 600 was found on northern Gotland during the midwinter counts from the shore (Gotland was not covered in 2007).

The Common Scoter as well as the Velvet Scoter is regularly wintering in the southeast part of the Kattegat (Figure 13, Table 4). At the aerial surveys in 2009, the total number of Common Scoters in this area was estimated to be about 17 500. The annual midwinter counts in this region do not cover the offshore parts properly, but large flocks of wintering Common Scoters have been regularly seen since the start of the counts in the late sixties (Nilsson 1975,2008$)$. 
Table 3. Estimated totals of Velvet Scoters Melanitta fusca in different areas along the Swedish Baltic coast in the winters 2007-2011. Distribution map for 2009 in Figure 12; further explanation in Table 1. A dash indicates absence of count.

Skattat antal svärta Melanitta fusca inom olika områden efter den svenska Östersjökusten 2007 och 2009. Utbredningskarta i Figur 12; ytterligare förklaring $i$ Tabell 1. Ett streck anger avsaknad av räkning.

\begin{tabular}{lrrrr}
\hline Area & 2007 & 2009 & 2010 & 2011 \\
\hline Falsterbo & 180 & 0 & 250 & 90 \\
Skåne south coast & 10 & 0 & - & 0 \\
Skåne southeast & - & 0 & - & 0 \\
Hanöbukten & 3240 & 60 & - & 330 \\
Blekinge archipelago & 0 & 30 & - & 0 \\
Kalmarsund & 870 & 0 & 325 & 13 \\
Öland east coast & 1850 & 0 & - & 0 \\
Öland North banks & 0 & 0 & 0 & 0 \\
Midsjöbankarna & - & 20 & 0 & 0 \\
Hoburg Bank & - & - & - & 350 \\
Gotland east coast & - & 100 & - & 1075 \\
Gotland north & - & - & - & 0 \\
Gotland west & - & - & - & - \\
Kalmar archipelago & - & - & - & ICE \\
Östergötland archipelago & - & - & - & ICE \\
Södermanland archipelago & - & - & - & ICE \\
Stockholm archipelago & - & 210 & ICE \\
Uppland coast & - & & & ICE \\
Gävlebukten & - & & & ICE \\
\hline Total & 6150 & & & 1858 \\
\hline
\end{tabular}

The local distribution of the Common Scoter in Hanöbukten is exemplified in Figure 14. In 2007, when the wintering population here was estimated to be around 13500 , the majority of the Common Scoters occurred far out at sea often at a water depth of about $20 \mathrm{~m}$ or more.

The Common Scoter has been seen in small numbers in the archipelagos of the Swedish Baltic coast in winter. The surveys in 2009 , which were timed for covering the Long-tailed Ducks, were too late for Scoters (and Eiders) as the spring migration for these species had already started.

Table 4. Estimated totals for Common Scoter Melanitta nigra and Velvet Scoter Melanitta fusca in Skälderviken and Laholmsbukten in the winter 2009.

Räknat och skattat bestånd för sjöorre Melanitta nigra och svärta Melanitta fusca $i$ Skälderviken och Laholmsbukten vintern 2009.

\begin{tabular}{lrr}
\hline Species & Skälderviken & Laholmsbukten \\
\hline Common Scoter Melanitta nigra & 4500 & 11000 \\
Velvet ScoterMelanitta fusca & 1320 & 1120 \\
Melanitta sp. & 750 & 1310 \\
\hline Total & 6580 & 13430 \\
\hline
\end{tabular}

\section{Eider Somateria mollisima}

Wintering Eiders are mostly found on the west coast of Sweden (Figure 15, Table 6). During the more or less complete count in 2009, about 52000 were counted on the west coast (Table 7) and about 20000 on the east coast (Table 6). The majority of the wintering Eiders in the Baltic were found in two areas, around the Falsterbo peninsula in the southwest and around Gotland (Figure 15, Table 6). Only smaller numbers were found in the other parts of the Baltic coast in winter. The 2009 survey was undertaken too late for counting of wintering Eiders in the archipelagos (migration had started), but only small numbers were found in the 2004 inshore survey, which had a good coverage of potential Eider sites in the archipelagos.

On the west coast, the Eider is well spread over the entire area from northern Öresund and Skälderviken in the south to the Norwegian border (Figure 16). In the Kattegat the Eiders are mostly found inshore, but in Bohuslän the majority of the Eiders were found close to the outer islands and skerries, mostly on the western shores of small islands with rich supplies of blue mussels. 


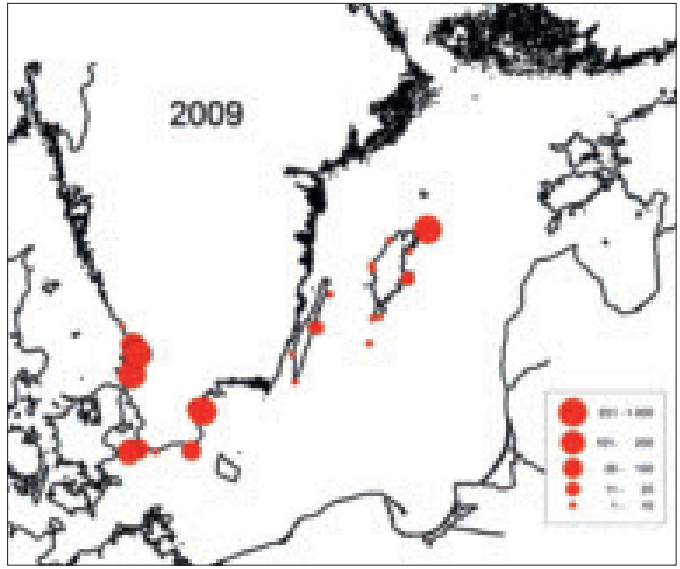

Figure 13. The distribution of Common Scoter Melanitta nigra in Swedish waters in the mild winter 2009.

Utbredningen för sjöorre Melanitta nigra $i$ svenska farvatten den milda vintern 2009.

Table 5. Estimated totals of Common Scoters Melanitta nigra in different areas along the Swedish Baltic coast in the winters 2007-2011. Distribution map for 2009 in Figure 13; futher explanation in Table 1. A dash indicates absence of count.

Skattat antal sjöorrar Melanitta nigra inom olika områden efter den svenska Östersjökusten 2007-2011. Utbredningskarta för 2009 i Figur 13; ytterligare förklaring $i$ Tabell 1. Ett streck anger avsaknad av räkning.
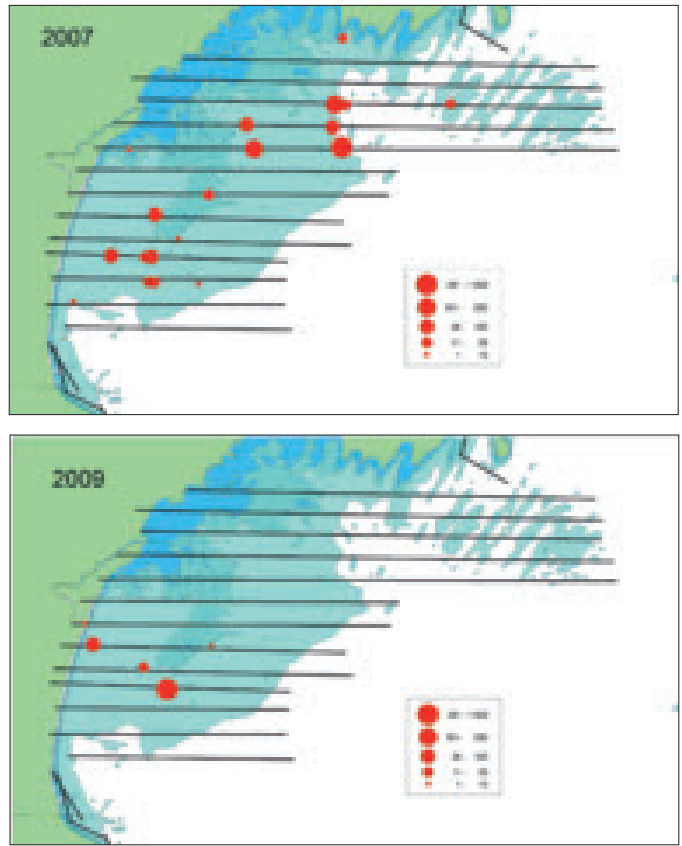

Figure 14. Number of Common Scoters Melanitta nigra counted along the line transects in Hanöbukten, southernmost Sweden during the winters 2007 and 2009. Black lines $=$ transect lines.

Antalet inräknade sjöorrar Melanitta nigra längs inventeringslinjer i Hanöbukten, södra Sverige, under vintrarna 2007 och 2009. Svarta linjer = inventeringslinjer.

\begin{tabular}{|c|c|c|c|c|}
\hline Area & 2007 & 2009 & 2010 & 2011 \\
\hline Falsterbo & 2100 & 470 & 300 & 375 \\
\hline Skåne south coast & 500 & 430 & - & 0 \\
\hline Skåne southeast & - & - & - & 0 \\
\hline Hanöbukten & 13500 & 300 & - & 238 \\
\hline Blekinge archipelago & 0 & 0 & - & 0 \\
\hline Kalmarsund & 20600 & 60 & 150 & 25 \\
\hline Öland east coast & 3200 & 560 & - & 500 \\
\hline Öland North banks & 0 & 0 & 0 & 0 \\
\hline Midsjöbankarna & - & 0 & 63 & 0 \\
\hline Hoburg Bank & - & 40 & 2110 & 338 \\
\hline Gotland east coast & - & 20 & - & 25 \\
\hline Gotland north & - & 600 & - & 0 \\
\hline Gotland west & - & 20 & - & - \\
\hline Kalmar archipelago & - & - & - & ICE \\
\hline Östergötland archipelago & - & - & - & ICE \\
\hline Södermanland archipelago & - & - & - & ICE \\
\hline Stockholm archipelago & - & - & - & ICE \\
\hline Uppland coast & - & - & - & ICE \\
\hline Gävlebukten & - & - & - & ICE \\
\hline Total & 39900 & 2500 & & 1501 \\
\hline
\end{tabular}




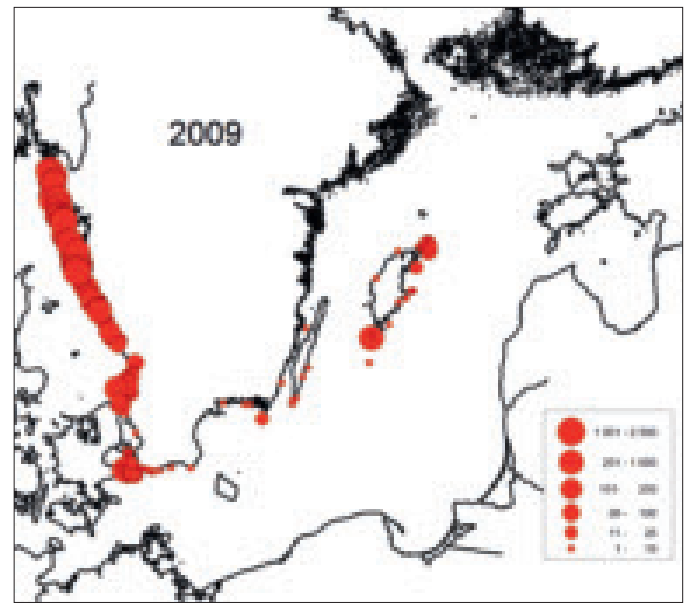

Figure 15. The distribution of Eider Somateria mollissima in Swedish waters in the mild winter 2009.

Utbredningen för ejder Somateria mollissima $i$ svenska farvatten den milda vintern 2009.

The Eiders wintering on the west coast have been surveyed from the air during four periods (Table 7). At the first two surveys less than 10000 wintering Eiders were found but from 1987-1989 to 2004 the number increased to 48300 with no large changes to 2009 when 52000 were counted here.
Table 7. Estimated totals of Eiders Somateria mollissima on the west coast in the four periods when aerial surveys were undertaken here (additional data from ground counts also included).

Beräknat antal ejdrar Somateria mollissima på västkusten vid de fyra tillfällen områdena flyginventerats (kompletterat med landbaserade räkningar).

\begin{tabular}{lrrrr}
\hline & $1971-74$ & $1987-89$ & 2004 & 2009 \\
\hline Bohuslän & 2900 & 5500 & 36600 & 40700 \\
Halland & 1200 & 2300 & 9300 & 5300 \\
NV Skåne & 4500 & 1900 & 2400 & 6000 \\
\hline Total & 8600 & 9700 & 48300 & 52000 \\
\hline
\end{tabular}

Red-breasted Merganser Mergus serrator The Red-breasted Merganser is well spread around the coasts of south Sweden occurring both in inshore and offshore waters (Figure 17). Numbers counted in the annual midwinter counts is large enough to allow the calculation of annual indices. In the 2009 survey the largest numbers counted in the Swedish part of the Baltic were found around the Falsterbo peninsula, in southern Kalmarsund and around Gotland. Only small numbers were found in the archipelagos as was also the case for the aerial surveys in the archipelagos and inshore

Table 6. Estimated totals of Eiders Somateria mollissima in different areas along the Swedish Baltic coast in the winters 2007-2011. Distribution map for 2009 in Figure 15. A dash indicates absence of count.

Skattat antal ejdrar Somateria mollissima inom olika områden efter den svenska Östersjökusten 2007-2011. Utbredningskarta för 2009 i Figur 15. Ett streck anger avsaknad av räkning.

\begin{tabular}{|c|c|c|c|c|}
\hline Area & 2007 & 2009 & 2010 & 2011 \\
\hline Falsterbo & 10500 & 12700 & 11660 & 9915 \\
\hline Skåne south coast & 300 & 90 & - & 348 \\
\hline Skåne southeast & - & - & - & - \\
\hline Hanöbukten & 1100 & 230 & - & 13 \\
\hline Blekinge archipelago & - & - & - & 0 \\
\hline Kalmarsund & 1500 & 780 & 363 & 0 \\
\hline Öland east coast & 3800 & 420 & - & 113 \\
\hline Öland North banks & 0 & 0 & 0 & 740 \\
\hline Midsjöbankarna & - & 9 & 0 & 0 \\
\hline Hoburg Bank & - & 90 & 0 & 40 \\
\hline Gotland east coast & - & 5400 & 675 & 6700 \\
\hline Gotland north & - & - & - & 0 \\
\hline Gotland west & - & - & - & - \\
\hline Kalmar archipelago & - & - & - & ICE \\
\hline Östergötland archipelago & - & - & - & ICE \\
\hline Södermanland archipelago & - & - & - & ICE \\
\hline Stockholm archipelago & - & - & - & ICE \\
\hline Uppland coast & - & - & - & ICE \\
\hline Gävlebukten & - & - & - & ICE \\
\hline Total & & 19719 & 12698 & 17869 \\
\hline
\end{tabular}



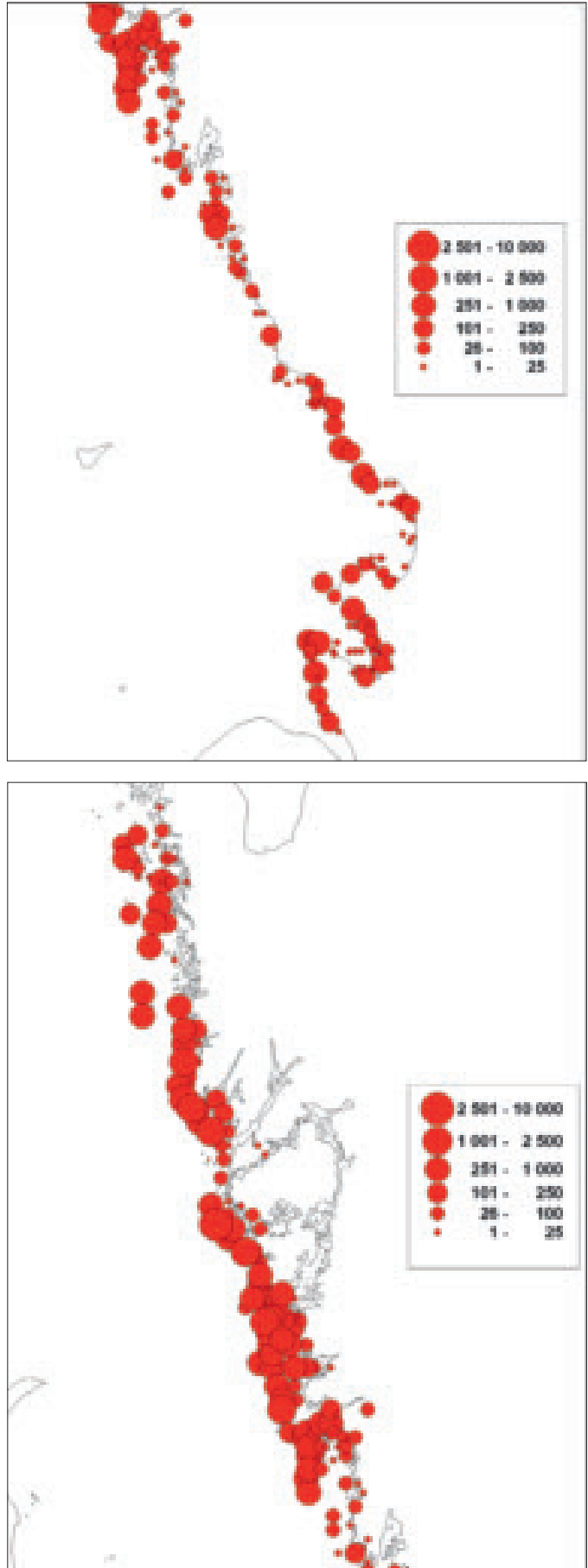

Figure 16. The distribution of Eider Somateria mollissima along the Swedish west coast during the winter 2009.

Ejderns Somateria mollissima utbredning efter den svenska västkusten vintern 2009

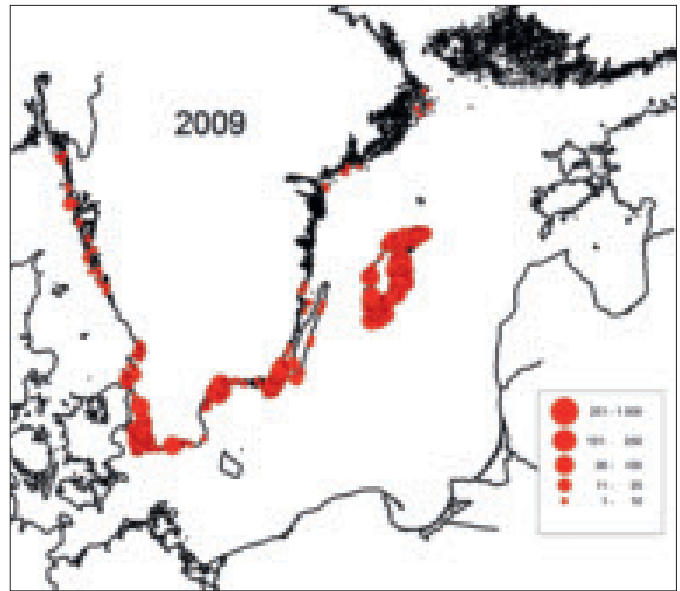

Figure 17. The distribution of Red-breasted Merganser Mergus serrator in Swedish waters in the mild winter 2009.

Utbredningen för småskrake Mergus serrator i svenska farvatten den milda vintern 2009.

areas in the early seventies and in 2004 (Nilsson 1975, 2008).

Based on the aerial surveys of the transects in the Baltic, adding grounds counts from the shore from areas not covered from the air gives an estimate of about 8000 Red-breasted Mergansers (Table 8). There is however a marked variation in the numbers of the species in the offshore Swedish waters. Thus the estimate for the waters around Falsterbo and the southern part of the Öresund was about 2000 for 2009, but censuses in connection with the Lillgrund offshore wind farm have given estimates of up to 12000 Red-breasted Mergansers in this area (Nilsson \& Green 2011). The surveys on the west coast in 2009 were aimed at covering Eiders (and Scoters in southern Kattegat) and do not allow an estimate of the wintering numbers of Red-breasted Mergansers here. In the Öresund about 900 were counted and close to 2000 were found on the west coast north of Öresund here at the country-wide surveys in 2004 (Nilsson 2008), so it is probable that the wintering population in Swedish waters in 2009 could be in the order of at least 11000 individuals. There is however a very marked variation between years as seen from the Lillgrund studies mentioned above.

There are unfortunately no comparable data to elucidate any changes in the overall population of the species in offshore Swedish waters. The Swedish Midwinter counts show a significant increasing trend since the start of the counts (Nilsson 2008), although numbers were low 
Table 8. Estimated totals of Red-breasted Mergansers Mergus serrator in different areas along the Swedish Baltic coast in the winters 2007-2011. Distribution map for 2009 in Figure 17. A dash indicates absence of count. Skattat antal småskrakar Mergus serrator inom olika områden efter den svenska Östersjökusten 2007-2011. Utbredningskarta för 2009 i Figur 17. Ett streck anger avsaknad av räkning.

\begin{tabular}{lrrrr}
\hline Area & 2007 & 2009 & 2010 & 2011 \\
\hline Falsterbo & 2600 & 2000 & 4510 & 2610 \\
Skåne south coast & 200 & 300 & - & - \\
Skåne southeast & - & - & - & 0 \\
Hanöbukten & 200 & 700 & - & 110 \\
Blekinge archipelago & 0 & 670 & 60 & 0 \\
Kalmarsund & 900 & 500 & - & 638 \\
Öland east coast & 300 & 0 & 0 & 1575 \\
Öland North banks & 0 & 0 & 60 & 102 \\
Midsjöbankarna & - & 0 & 0 & 0 \\
Hoburg Bank & - & 1700 & - & 238 \\
Gotland east coast & - & - & - & 163 \\
Gotland north & - & 825 & - & 0 \\
Gotland west & - & 0 & - & - \\
Kalmar archipelago & - & 0 & - & ICE \\
Östergötland archipelago & - & 0 & - & ICE \\
Södermanland archipelago & - & 0 & - & ICE \\
Stockholm archipelago & - & 0 & & ICE \\
Uppland coast & - & 7840 & ICE \\
Gävlebukten & - & & & ICE \\
\hline Total & & 0 & - & \\
\hline
\end{tabular}

\section{Discussion}

From the data presented here and in comparison with the estimates from the total surveys of wintering seabirds in the Baltic (Durinck et al. 1994, Skov et al. 2011; see also Delany \& Scott 2006 for the entire NW Europe) it is clear that the Swedish offshore areas in the Baltic are of very large international importance for wintering seaducks, especially for the Long-tailed Duck but also for the Red-breasted Merganser (Nilsson 2008) whereas the two scoter species are more sparse.

When comparing the estimates for Swedish waters presented here with the population estimates for NW Europe presented by Delany \& Scott (2006) and with the two All Baltic surveys (Durinck et al. 1994, Skov et al. 2011) it is important to bear in mind the differences in methods used during the two all Baltic surveys with the different uncertainties and biases attached to the two methods (see above). These factors will also have a great importance when evaluating the population changes indicated in the report from the SOWBAS study (Skov et al. 2011).

The results of the two all-Baltic surveys indicate a very marked decrease in the population of Longtailed Duck between the two surveys, from 4.3 to 1.5 million (Skov et al 2011). The Swedish winter- ing population was $32 \%$ and $29 \%$ of the published estimates for the entire Baltic in the two surveys, showing that the decline was similar in Swedish waters as elsewhere. The decrease in the population within Swedish waters was mainly concentrated to Hoburgbank and the offshore waters of east Gotland, whereas there was no such decrease for the Midsjö banks and with stable wintering numbers or only smaller decreases (within the calculation error) established for the wintering areas around Öland and along the mainland coast.

In spring, the Long-tailed Ducks migrate to the breeding areas in northern Russia, a major part of the population passing the Gulf of Finland. During this migration the numbers have been counted from sites in Finland and Estonia (Bergman 1974, Hario et al. 2009). Counts at Söderskär on the Finnish coast showed an increase from about 1970 to the early 1990s, followed by a marked decrease (Hario et al. 2009, see also Kauppinen \& Leivo 2008). The highest counts of spring migrants coincided with the first all Baltic survey (1992/1993), which yielded much higher estimates than the 2007-2009 survey. Unfortunately there are no available data to show whether there has been a similar increase in the numbers of wintering Long-tailed Ducks in the Baltic as indicated from the Finnish migration 
counts. The only winter censuses from the seventies are the ones presented here which do not cover the important offshore banks, which are used by the majority of Long-tailed Ducks in Swedish waters.

Different factors have been discussed in relation to the marked decline of the Long-tailed Ducks during recent years such as oil pollution, bycatches in fishing equipment and decreased habitat quality (Larsson \& Tydén 2005, Stempniewicz 1994, Skov et al. 2011, Zydelis et al. 2009) but also factors on the breeding areas on the Russian tundra( Hario et al.2009). Probably the decline of the wintering Long-tailed Duck population is caused by a combination of different factors. The availability and quality of the food is probably an important factor here as there have been marked decreases among several mussel eaters in the Baltic. The steady impact of small discharges of oil has certainly had an important impact on the wintering Long-tailed Ducks (Larsson \& Tydén 2005). The most marked decline in the Swedish waters was found for the Hoburg bank and the east coast of Gotland, these waters being on the main shipping line to the Bay of Finland and St Petersburg. There are also indications on a low rate of young production that can either be related to factors on the breeding grounds in Russia or to a decline in the quality of the food for the females building up the condition before the migration to the breeding areas.

The idea has also been put forward that the decline in the Baltic Sea reflects a change in the winter distribution of the species, but there are no data supporting this idea. Within the Baltic all potential winter areas were surveyed during the SOWBAS study.

Similar to the Long-tailed Duck, the Common Scoter and the Velvet Scoter both have large wintering populations in the Baltic Sea and both have decreased markedly (Skov et al. 2011). These species have only small wintering populations in Swedish waters. The same applies to the winter population of Eiders in the Swedish part of the Baltic. The large numbers of breeding Eiders from the Swedish Baltic coast leave the country for the winter and are mainly found in the southwestern part of the Baltic and the Kattegat (Desholm et al. 2002, Ekroos et al. 2012).

The Swedish breeding population of the Eider showed a marked increase from the first larger studies in the seventies to the nineties, followed by a very marked decrease back to the level recorded in the seventies (Ekroos et al. 2012). Marked decreases have also been found in the wintering pop- ulation of the whole northwestern Europe. In contrast to this there has been no decrease in the size of the wintering numbers of Eiders on the Swedish west coast. One cannot avoid drawing attention to the fact that that there is a parallel between the numerical patterns of wintering Long-tailed Ducks and breeding Eiders. In both species there was a long term increase to a peak followed by a decline, similar patterns even if they did not peak at exactly the same time. In the Eider, change in food availability (mussels) has been advanced as an explanation, and I consider it likely that the same factor may have played a role for the Long-tailed Duck.

The four seaduck species discussed above all show marked decreases between the two large surveys. All four species are benthic feeders to a large extent relying on mussels. The fifth species common in the Swedish offshore waters, the Redbreasted Merganser, is a fish-eater. According to the SOWBAS study (Skov et al. 2011) there are indications of a decrease also for this species, but the data from Swedish waters indicate an increasing trend. In contrast to the offshore species discussed here, counts of inshore seaducks (and other diving ducks) mainly show increasing trends (Nilsson 2008).

\section{Acknowledgements}

The offshore aerial surveys reported here as well as the Swedish Midwinter Counts are supported by grants from Naturvårdsverket (the Swedish Environmental Protection Agency). The same applies to the aerial surveys in the seventies which were also supported by the Swedish Airforce, which provided free flying time. I am also grateful for the support of the Swedish Coast Guard that allowed duck counters onboard their patrol ships during the surveys in the sixties and seventies.

The aerial surveys could not have been done without the help of a number of skilled observers and I will give my sincere thanks to David Erterius, Martin Granbom, Martin Green, Nils Kjellen, Johan Nilsson, Roine Strandberg and Mikael Svensson for many observer hours over the open sea. Martin Green kindly commented on an earlier version of the manuscript.

Permission to publish the maps in the figures granted by Sjöfartsverket $\subset$ 12-01905.

\section{References}

Bergman, G. 1974. The spring migration of the Long-tailed Duck and the Common Scooter in western Finland. Ornis 
Fennica 51: 129-145

Delany, S. \& Scott, D., eds. 2006. Waterbird Population Estimates - Fourth Edition. Wetlands International, Wageningen, The Netherlands.

Dersholm, M., Christensen, T.K., Hario, M., Andersson, Å., Ens, B., Camphuysen, C.J., Nilsson, L., Waltho, C.M., Lorentsen, S-H., Kuresoo, A., Kats, R.K.H., Fleet,D.M. \& Fox, A.D. 2002. Status of the Baltic/Wadden Sea population of the Common Eider Somateria m. mollissima. Wildfowl 53: 167-203.

Durinck, J., Skov,H., Jensen, F.P. \& Pihl, S. 1994. Important Marine Areas for Wintering Birds in the Baltic Sea. Ornis Consult, Copenhagen, Denmark.

Ekroos, J., Fox, A.D., Christensen, T.K., Petersen, I.K., Kilpi, M., Jonsson, J.E., Green, M., Laursen, K., Cervencl, A., de Boer, P., Nilsson, L., Meissner, W., Garthe, S. \& Öst, M. 2012. Declines amongst breeding Eider Somateria mollissima numbers in the Baltic/Wadden Sea flyway. Ornis Fennica 89: in print.

Haapanen, A. \& Nilsson, L. 1979. Breeding waterfowl populations in northern Fennoscandia. Ornis Scandinavica 10: $145-219$.

Hario, M., Rintala, J. \& Nordenswan, G. 2009. (Dynamics of wintering long-tailed ducks in the Baltic Sea - the connection with lemming cycles, oil disasters and hunting). Suomen Riista 55: 83-96 (Finnish with English summary)

Kauppinen, T.J. \& Leivo, K.M. 2008. Vaimeneeko allin laulu? Suomen Luonto 2: 20-25. (In Finnish)

Larsson, K. \& Tydén, L. 2005. Effekter av oljeutsläpp på övervintrande alfågel Clangula hyemalis vid Hoburgs bank i central Östersjön mellan 1996/97 och 2003/04. Ornis Svecica 15: 161-171.

Joensen, A.H. 1974. Wildfowl populations in Denmark 1965-1973. A survey of non-breeding populations of Ducks, Swans and Coot and their shooting utilization. Danish Review of Game Biology 9(1): 1-206.

Mathiasson, S. 1970. Numbers and distribution of Longtailed Ducks wintering in northern Europe. British Birds 63: 414-424.

Nilsson, L. 1972. Habitat Selection, Food Choice and Feeding Habits of Diving Ducks in Coastal Waters of South Sweden during the Non-breeding Season. Ornis Scandinavica 3: 55-78.

Nilsson, L. 1975. Midwinter distribution and numbers of Swedish Anatidae. Ornis Scandinavica 7:193-205.

Nilsson, L. 1977. November distribution and numbers of Swedish Anatidae. Viltrevy 10: 41-77.

Nilsson, L. 1980. De övervintrande alfåglarnas Clangula hyemalis antal och utbredning längs den svenska kusten. Vår Fågelvärld 39: 1-14.

Nilsson, L. 2008. Changes in numbers and distribution of wintering waterfowl in Sweden during forty years, 19672006. Ornis Svecica 18: 135-226.

Nilsson, L. \& Green, M. 2011. Birds in the southern Öresund in relation to the windfarm at Lillgrund. Final report of the monitoring program 2001-2011. Report from Biologiska Institutionen, Lunds Universitet.

Skov, H., Heinänen, S., Zydelis, R., Bellebaum, J., Bzoma, S., Dagys, M., Durinck, J., Garthe, S., Grishanov, G., Hario, M., Kieckbusch, J.J., Kube, J., Kuresoo, A., Larsson, K., Luigujoe, L., Meissnerm, W., Nehls, H.W., Nilsson, L., Petersen, I.K., Roos, M., Pihl, S., Sonntag, N., Stock, A. \& Stipniece, A. 2011. Waterbird Population and Pres- sures in the Baltic Sea. Tema Nord 2011: 550.

Stempniewicz, L. 1994. Marine birds drowning in fish nets in the Gulf of Gdansk (southern Baltic): numbers, species composition, age and sex structure. Ornis Svecica 4: 123-132.

Zydelis, R., Bellebaum, J., Österblom, H., Vetemaa, M., Schirmeister, B., Stipniece, A., Dagys, M., van Eerden, M. \& Garthe, S. 2009. Bycatch in gillnet fisheries - An overlooked threat to waterbird populations. Biological Conservation 142: 1269-1281.

\section{Sammanfattning}

Årliga midvinterinventeringar av övervintrande sjöfåglar har organiserats i Sverige sedan 1967 som en del av de Internationella Midvinterinventeringarna samordnade av Wetlands International (Nilsson 2008). Dessa inventeringar utgör nu en del av det nationella miljöövervakningsprogrammet. Under de första åren försökte man täcka så stora områden som möjligt (Nilsson 1975), men senare koncentrerades inventeringarna till att täcka ett representativt urval lokaler för att ge underlag för beräkning av årliga index för de viktigaste arterna.

Under åren 1965-1978 genomfördes ett betydande antal båtinventeringar utanför de svenska kusterna från kustbevakningens patruller, varvid betydande områden i skärgårdarna och utanför de öppna kusterna kunde täckas (Nilsson 1972, 1980). Omfattande flyginventeringar genomfördes också i skärgårdarna och längs de öppna kusterna under dessa år (Nilsson 1975). Vissa offshore områden kunde också täckas med flyg.

De tidiga undersökningarna under 1960- och 1970-talen gav en hel del information om de havslevande dykändernas förekomst i svenska farvatten, något som tidigare varit ganska dåligt känt (jfr dock Mathiasson 1970). Under dessa år var det emellertid inte möjligt att täcka in utsjöbankar som Midsjöbankarna och Hoburgs Bank, som redan då var kända som viktiga lokaler för speciellt alfågel.

Efter de politiska förändringarna i området genomfördes en första samordnad inventering med båt och flyg i hela Östersjön 1992 och 1993 (Durinck et al. 1994). Denna inventering upprepades under åren 2007-2009 i SOWBAS-projektet (Skov et al. 2011). Parallellt med dessa undersökningar genomfördes under 2009-2011 på Naturvårdsverkets uppdrag inventeringar i de svenska farvattnen med flyg för att kartlägga sjöfågelförekomsten och för att utarbeta ett förslag på hur dessa fåglar skall kunna följas upp inom övervakningsprogrammen.

I denna uppsats sammanfattas resultaten från inventeringarna $\mathrm{i}$ de svenska farvattnen under 2007-2011 och jämförs med de inventeringar som 
genomförts i de inre farvattnen och vissa utsjöområden under den tidiga inventeringsperioden samt med resultaten från den första sammanfattande inventeringen av Östersjön (Durnick et al. 1994, Nilsson 1975, 1980). Jag koncentrerar mig här på de arter som täcks dåligt av de traditionella midvinterinventeringarna, dvs. alfågel, svärta, sjöorre, ejder och småskrake. De båda sistnämnda ses i tillräcklig omfattning vid de årliga midvinterinventeringarna för att ge underlag för indexberäkningar (Nilsson 2008), men de förekommer också i utsjöområdena och behandlas därför också i detta sammanhang.

\section{Material och metodik}

Vid inventeringarna 2007-2011 täcktes de yttre havsområdena med linjetaxeringar från flygplan. Inventeringslinjerna lades ut så att de täckte alla viktigare havsområden (inkl. utsjöbankar) i de svenska havsområdena. Gränsen mot djupare vatten lades vid ett djup på $30 \mathrm{~m}$. Ett exempel på utlägg av inventeringslinjer visas från Hanöbukten (Figur 1). Här låg linjerna med $2 \mathrm{~km}$ mellanrum, men i de flesta havsområden låg de med $4 \mathrm{~km}$ mellanrum. I ostkustskärgårdarna startade linjerna $\mathrm{i}$ princip i zonen med större öar och gick ut till djupt vatten.

Vid flyginventeringarna använde vi en CESSNA 337 Skymaster, en tvåmotorig högvingad maskin, godkänd för utsjöflygningar, och med god sikt. Normalt flög vi på ca $70 \mathrm{~m}$ höjd med en hastighet av ca $150-180 \mathrm{~km} / \mathrm{h}$. Navigeringen skedde mellan förutbestämda punkter med planets GPS. Vid observationerna medverkade minst två observatörer, en bredvid piloten och en bakom, vilka täckte var sin sida av planet. Ibland medföljde en tredje observatör. Alla iakttagelser talades in på band med tidsangivelse. Den exakta flygvägen loggades på en separat GPS. Observationerna lades sedan in i en databas med exakta positioner för varje observation.

Vid inventeringarna räknade vi samtliga observerade fåglar. Inventeringarna koncentrerades till ett band på $200 \mathrm{~m}$ på vardera sidan av flygplanet. Fåglar utanför denna zon noterades som extra information och markerades speciellt i databasen. Observatörerna hade en död zon på vardera sidan av planet, som beräknas till ca $40 \mathrm{~m}$ på vardera sidan. Detta innebär i praktiken att den inventerade zonen blir $320 \mathrm{~m}$ bred. Vid analyserna har sedan inventeringsdata från denna $400 \mathrm{~m}$ breda zon omräknats till antal individer per större områden baserat på räkningarna $\mathrm{i}$ inventeringsbältet och uppräk- ningsfaktor (6,25 resp. 12,5 för inventeringslinjer med 2 resp. $4 \mathrm{~km}$ lucka) baserad på täckningsgraden inom relevanta djupområden.

Under 2007 kunde endast begränsade inventeringar genomföras i sydligaste Sverige, medan mer omfattande inventeringar gjordes under 2009-2011 (Figur 2). Vädermässigt skilde sig vintrarna åt markant. 2009 (liksom 2007) var en mild vinter med endast ringa isläggning, medan 2010 och 2011 var hårda isvintrar i Östersjön. Bland annat var Kalmarsund och skärgårdarna norr därom täckta med is liksom stora delar av östra Östersjön (jfr. Figur $5)$.

Resultaten från inventeringarna 2007-2011 jämförs nedan med de båda större Östersjöinventeringarna 1992/93 och 2007-2009 (Durinck et al. 1994, Skov et al. 2011). Vid jämförelserna måste man beakta att den svenska inventeringen 2007 2011 grundas på täta linjetaxeringar med flyg, medan många av de svenska områdena 1992/93 endast kunde täckas med ett fătal inventeringslinjer från båt. Skattningarna grundas i betydande utsträckning på modellering, vilket innebär att det föreligger en betydande osäkerhet i många värden. Vid den senare inventeringen användes också modellering för totalskattningarna av Östersjön, men underlaget från de svenska vattnen var betydligt bättre. De i denna uppsats redovisade skattningarna baseras direkt på inventeringarna och de nämnda uppräkningsfaktorerna.

\section{Resultat}

Alfågel

Alfåglarna efter den svenska kusten är starkt begränsade till Östersjön med endast enstaka på västkusten (Figur 3). Merparten av alfåglarna vintern 2009 observerades på de tre utsjöbankarna: Hoburgs bank och de båda Midsjöbankarna. Totalt sågs här ca $300000 \mathrm{av}$ totalt beräknade 436000 för hela det svenska området (Figur 3, 4, Tabell 1). Betydande antal återfanns också runt Ölands och Gotlands kuster, Hanöbukten, Kalmarsund samt ytterskärgårdarna från Kalmarsund till Stockholms skärgård.

De båda vintrarna 2010 and 2011 med hårda isförhållanden medförde en helt annan utbredning för alfåglarna i de svenska farvattnen. Totalt beräknades antalet alfåglar på de tre viktigaste utsjöbankarna till 6300002010 och 365000 2011. Vintern 2010 beräknades inte mindre än 426000 alfåglar för Hoburgs bank. En viktig orsak till dessa höga antal på de svenska utsjöbankarna är isläget i Östersjön. De viktiga alfågelområdena i Irbesundet 
och Rigabukten var helt istäckta och man kan anta att många av dessa alfåglar sökte sig till de svenska farvattnen.

Vid den tidigare totalinventeringen av Östersjön beräknades beståndet för de svenska farvattnen till 1,4 miljoner att jämföras med 0,44 miljoner 2009, en mycket markant nedgång, men den exakta storleken på nedgången är svårbedömt då skattningarna 1992/93 och 2007-2009 grundas på olika metoder.

Från flera viktiga områden föreligger data också från 1970-talet (Tabell 1, se också Nilsson 1980). För Hanöbukten och skärgårdsområdena föreligger det inga klara skillnader mellan 1970-talets inventeringar och de sentida inventeringarna, medan inventeringarna norr och öster om Öland antyder en nedgång av beståndet. Tyvärr saknas mer omfattande data från Gotland. Vid en flyginventering 1974 räknades 26000 alfåglar efter inventeringslinjen, vilket med erfarenheter från de senare inventeringarna kan antas motsvara ett övervintrande bestånd på 200 000-400 000. Inom vissa områden täcks alfåglarna väl av de årliga midvinterinventeringarna från land (Figur 5). För den skånska sydkusten och Blekinges skärgård noteras signifikanta nedåtgående trender, medan det inte finns några klara trender för antalet alfåglar vid norra Öland samt vid Väddö i Uppland.

Alfåglarnas utbredning inom olika avsnitt av den svenska kusten exemplifieras i en serie regionala kartor från de viktigaste alfågelområdena efter den svenska kusten (Figur 6-11). Detaljutbredningen på de viktiga utsjöbankarna Midsjöbankarna och Hoburgsbanken diskuteras inte närmare här, då alfåglarnas uppträdande här är föremål för speciella undersökningar och kommer att behandlas i ett annat sammanhang.

I Hanöbukten och utanför Ölands ostkust är alfåglarna fördelade ut till ett djup av ca $30 \mathrm{~m}$. För Hanöbukten visade inventeringarna på betydande skillnader mellan olika år. Vid något tillfälle förekom alfåglarna väl spridda, medan de under andra inventeringar var tämligen koncentrerade till vissa bankar, t.ex. Kiviksbredan, som vid båtinventeringar på 1960-talet konstaterades vara en viktig lokal. Vid Öland noterades koncentrationer vid södra Öland samt runt norra Ölands bankar. I skärgårdarna från Kalmarsund och norrut förekom de flesta alfågelflockar vid havsgrund främst i den yttre skärgådszonen.

\section{Svärta}

Svärtan förekommer i relativt låga antal efter den svenska kusten under vintern (Tabell 3, 4). Vid inventeringen 2009 förekom den i någorlunda antal bara i södra Kattegatt där ca 2500 individ noterades, medan antalet svärtor i Östersjön var betydligt lägre (Figur 13).

\section{Sjöorre}

Sjöorren är en regelbunden vintergäst i den södra delen av den svenska Östersjökusten samt i Laholmsbukten och Skälderviken i södra Kattegatt (Tabell 4, 5). Vid inventeringen i delar av undersökningsområdet vintern 2007 beräknades antalet sjöorrar till ca 40000 i Hanöbukten, södra Kalmarsund och runt Öland (Tabell 5), men betydligt lägre antal fanns här de andra undersökningsåren. Beståndet i södra Kattegatt beräknades 2009 till 13 500. Sjöorrens utbredning vintern 2009 visas i Figur 13 och detaljutbredningen i Hanöbukten under två vintrar i Figur 14.

\section{Ejder}

I Sverige återfinns merparten av de övervintrande ejdrarna på Västkusten, medan Östersjöns häckande ejdrar i huvudsak lämnar den svenska delen av Östersjön under vintern (Figur 15, Tabell 6, 7). Vid inventeringarna 2009 beräknades beståndet på den svenska västkusten till ca 52000 , medan det fanns ca 20000 övervintrande ejdrar i den svenska delen av Östersjön. Längs västkusten förekom ejdern spridd från norra Öresund till den norska gränsen med den största delen i Bohuslän (Figur 16). I Kattegatt fanns de i huvudsak i de ganska strandnära områdena, medan merparten av Bohusläns ejdrar fanns i ytterskärgården, huvudsakligen på öarnas västsidor där de rikaste musselbankarna finns. Det övervintrande ejderbeståndet på västkusten har inventerats vid fyra tillfällen (Tabell 7). Från 1987/89 till 2004 ökade antalet övervintrare från mindre än 10000 till 48 300, medan endast en mindre ökning skedde därefter till 520002009.

\section{Småskrake}

Småskraken var 2009 väl spridd efter kusterna i södra Sverige både i de inre farvattnen och i utsjövattnen, men förekomsten i skärgårdarna liksom på västkusten var ganska sparsam (Figur 17, Tabell 8). Flertalet småskrakar fanns efter kusterna av Skåne, södra Kalmarsundsregionen samt Gotland. Totalt beräknades beståndet till ca 9000 individer, varav 8000 på ostkusten (Tabell 8) och ca $1000 \mathrm{i}$ Öresund och västkusten.

\section{Diskussion}

De här presenterade inventeringarna i relation till de båda Östersjöinventeringarna (Durinck et al. 
1994, Skov et al. 2011), där de svenska inventeringarna ingår, visar klart att de svenska farvattnen i Östersjön är av stor betydelse internationellt för det övervintrande beståndet av alfågel.

Vid den första inventeringen (Durinck et al. 1994) beräknades totalbeståndet av alfågel i Östersjöområdet till 4,3 miljoner, varav 1,4 miljoner fanns i de svenska farvattnen, främst på Hoburgs Bank och områdena öster om Gotland. Inventeringen 2007-2009 (Skov et al. 2011) gav 1,5 miljoner för hela Östersjön, medan beståndet i de svenska farvattnen här skattas till 0,43 miljoner. Betydligt högre antal noterades i de svenska vattnen under isvintern 2010, då områdena vid Rigabukten var helt frusna.

Även om skillnaderna i inventeringsmetodik mellan de båda storinventeringarna gör dem svåra att jämföra står det klart att alfågelbeståndet minskat markant sedan 1990-talet. I de svenska farvattnen är detta mest markant för Hoburgs Bank och farvattnen runt Gotland och förmodligen till en del vid Öland, medan fastlandets skärgårdar visar ungefär samma alfågelbestånd som på 1970-talet. En signifikant minskande trend har dock noterats längs kusterna av Blekinge och södra Skåne.

Flera faktorer har framförts som möjliga orsaker till alfåglarnas markanta beståndsnedgång såsom oljeföroreningar, bifångster vid fiske, men också att förhållandena på häckningsområdena ändrats (Hario et al. 2009, Larsson \& Tydén 2005, Stempniewicz 1994, Skov et al. 2011, Zydelis et al. 2009). Det minskande antalet alfåglar i Östersjön sedan 1990-talet återspeglas också i sträckräkningar från den finska kusten (Hario et al. 2009, se also
Kauppinen \& Leivo 2008), vilka också antyder en ökning av antalet från 1970- talet till 1990-talet före den markanta nedgången.

Även för svärtan och sjöorren, som endast övervintrar i mindre antal i de svenska vattnen, visar de internationella inventeringarna en nedgång $\mathrm{i}$ Östersjöbeståndet (Skov et al. 2011). För ejdern som är en viktig häckfågel efter den svenska kusten har beståndet visat en mycket markant ökning från 1970-talet till senare delen av 1990-talet följt av vad som kan betecknas som en populationskrasch (Desholm et al. 2002, Ekroos et al. 2012). Denna minskning i ejderbeståndet noterades först för de övervintrande ejdrarna främst i de danska farvattnen (Desholm et al. 2002). Huvuddelen av Östersjöns ejdrar övervintrar utanför de svenska farvattnen i främst i sydvästra Östersjön och Kattegatt samt Wadehavet, och någon minskning har inte setts i det svenska vinterbeståndet.

SOWBAS rapporten (Skov et al. 2011) visar också en nedgång för det övervintrande beståndet av småskrake i Östersjön. Regionalt konstaterades minskningar för de flesta områden, men de svenska midvinterinventeringarna visar en ökande trend. Underlaget för att bedöma populationsförändringar hos arten är emellertid inte det bästa eftersom bl.a. viktiga svenska farvatten inte var adekvat representerade i de större inventeringarna. Som kontrast till minskningarna hos de övervintrande bestånden av dykänder i uthavsområdena visar flertalet av de dykänder som övervintrar nära kusterna, liksom övriga dykänder, ökande eller stabila vinterbestånd (jfr Nilsson 2008). 